British \& Irish Botany 3(2): 232-262, 2021

\title{
Fifteen years of habitat, floristic and vegetation change on a pioneer sand-dune and slack system at Ainsdale, north Merseyside, UK
}

\author{
Philip H. Smith*, Patricia A. Lockwood \\ Formby, Liverpool, UK \\ *Corresponding author: Philip H. Smith: philsmith1941@tiscali.co.uk
}

This pdf constitutes the Version of Record published on $26^{\text {th }}$ July 2021

\begin{abstract}
Changes in habitat, floristics and vegetation between 2005 and 2019 were studied on 2.9 ha of sandy foreshore near Ainsdale-on-Sea, north Merseyside. Named the 'New Green Beach', the site initially supported saltmarsh vegetation but, within five years, a 30-35 m-wide embryo dune ridge had formed, eventually $3.5 \mathrm{~m}$ high, backed by a $300 \times 30 \mathrm{~m}$ seasonally flooded, calcareous dune-slack. The latter was colonised by pioneer slack plants, after which it rapidly developed areas of tall-herb fen and Alnus/Salix carr, while saltmarsh plants declined. During succession, species recorded as 'rare' became fewer in number while a higher frequency of 'abundant' taxa was recorded. The number of vascular plants listed annually increased from one in 2005 to 154 in 2019. Overall, 246 taxa were identified, turnover losses increasing over time. Only $9 \%$ of the recorded taxa were non-native, $17 \%$ being regionally or nationally notable, including 16 Red-listed species. Very poor statistical fits were obtained to recognised UK National Vegetation Classification vegetation types. Analysis of Ellenberg Indicator Values for salinity, nitrogen, moisture and reaction showed that the plant community became progressively adapted to low salinity, lower fertility, drier conditions and a less basic soil. The findings are discussed in relation to comparable studies elsewhere in Britain and Northern Europe. The rate of succession on the New Green Beach seems remarkably high, while evidence of declining soil fertility over time was unexpected.
\end{abstract}

Key words: Ellenberg indicator values; habitat characteristics; nature conservation; primary dune-slack; succession; vascular plants.

\section{Introduction}

Coastal sand-dunes provide a unique opportunity to study primary succession from an exposed beach plain. Often, the resulting habitats occur in clearly defined zones that can be dated, indicating rates of change. The plant communities of these successional stages have been well studied but floristic 
change during the early part of dune succession is less well understood (Ranwell, 1972; Rodwell, 2000). Pioneer dune-slacks, in particular, show high speciesrichness and variable species composition, partially mediated by soil conditions and ground-water regime. Species of conservation significance are often found preferentially in these early stage successional dune habitats (Davy et al., 2006; Lammerts et al., 2001; Sival \& Grootjans, 1996; Sýkora et al., 2004).

From 1986 onwards, the upper part of the sand/silt foreshore between Birkdale and Ainsdale in north Merseyside, (National Grid References SD321163 to SD302136) (v.c.59 South Lancashire) became extensively colonised by vegetation (Edmondson et al., 2001; Smith, 2007; 2010). At first, the plant community was dominated by Puccinellia maritima (common saltmarsh-grass), which trapped sand and silt to produce low hummocks. From these, a zone of embryo dunes formed, 50-100 m west of the original dune frontage. Impeded drainage inland of the dune ridge created a series of shallow, seasonally flooded, primary dune-slacks. Becoming known as 'Birkdale Green Beach', this feature eventually extended for over $4 \mathrm{~km}$, covering about 64 ha, its high biodiversity being described by Smith (2007).

Rapid rates of sediment deposition on the foreshore seems to have been the main factor leading to vegetation colonisation, while restricting vehicle access to this section of beach from 1993 onwards may also have contributed (Connolly, 2006; Smith, 2007; 2010). Changes to the mechanical beach-cleaning regime enacted from 1997 by the land-owner, Sefton Metropolitan Borough Council, with the aim of reducing damage to vegetation and protecting embryo dunes, also played a role in Green Beach formation (McAleavy, 2010).

In autumn 2004, another contiguous area of sandy shore to the south, about $360 \mathrm{~m}$ long and $80 \mathrm{~m}$ wide and covering 2.9 ha (SD30171383 to SD30041350) was fenced off, having previously been part of the Ainsdale beach carpark (Fig. 1). This paper describes the changes in habitat characteristics, floristics and vegetation over the subsequent 15 years within this area, known as the 'New Green Beach'.

\section{Methods}

From September 2005 to October 2019, approximately monthly visits were made between spring and autumn to record habitat characteristics and vascular plants on the New Green Beach. Their relative abundance was recorded on the DAFOR scale (dominant; abundant; frequent; occasional; rare). Ellenberg salinity (S), nitrogen $(N)$, moisture $(F)$ and reaction $(R)$ indicator values for the species found each year were obtained from Hill et al. (2004). In late summer 2017, eleven 2 $\mathrm{m} \times 2 \mathrm{~m}$ quadrats were recorded in the slack using UK National Vegetation Classification (NVC) methodology (Rodwell, 2000). Quadrat locations were selected to represent three typical vegetation stands: the southern part of the slack with much Salix repens (Creeping Willow); dry-slack on the western fringe; tall-herb fen in the northern half of the slack. Quadrat samples were analysed using TABLEFIT to determine the degree of fit to known NVC communities and 
sub-communities (Hill, 2015). Sub-surface soil samples were taken to determine $\mathrm{pH}$ using a Lutron $\mathrm{PH}-212 \mathrm{pH}$ meter buffered at $\mathrm{pH} 4$ and 7.

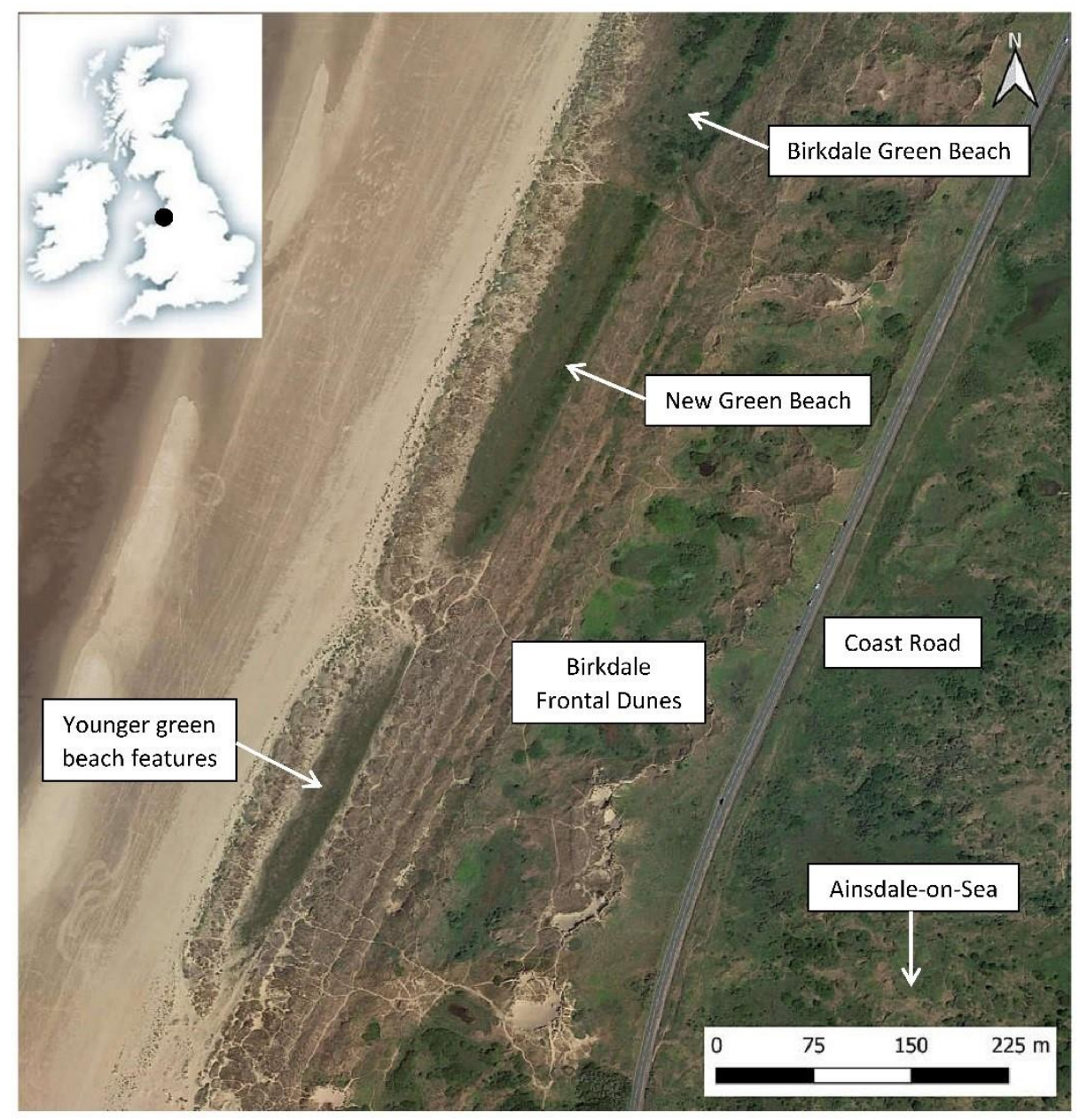

Figure 1. Aerial photograph of study area. Inset shows location of the Sefton Coast (Map created using the free and open source QGIS)

\section{Results}

Habitats

As was observed on the original Birkdale Green Beach (Edmondson et al., 2001; Smith, 2007; 2010), the first colonists in 2004-05 were scattered plants of Puccinellia maritima (Fig. 2). By 2007, an embryo dune ridge, eventually 30-35 m wide, had developed around $P$. maritima plants along the seaward fringe of the New Green Beach, about $40 \mathrm{~m}$ from the original dune frontage (Fig. 3). Within five years, many of these 'proto-dunes' were up to $1.5 \mathrm{~m}$ high (mostly $0.5-1.0$ $\mathrm{m}$ ) and had been colonised on their crests by Elymus junceiformis (Sand Couch), Leymus arenarius (Lyme-grass) and, more rarely, Ammophila arenaria (Marram) (Fig. 4). During the early years of the study, equinoctial and storm-driven highspring tides inundated the site with seawater several times a year. However, once the outer ridge was well established in about 2010, marine incursion was 
rare, an exception being the major storm-surge of December 2013, which breached the dune ridge in several places, flooding the slack with seawater. By 2015 the embryo and yellow (mobile) dunes were at least $3 \mathrm{~m}$ high, increasing to $3.5 \mathrm{~m}$ in 2019 (Fig. 5). They were dominated by dense $A$. arenaria, together with patches of $L$. arenarius, while the leeward slope had a more diverse plant community, including large patches of Euphorbia paralias (Sea Spurge). In some years, strandline vegetation, especially of Atriplex prostrata (Spear-leaved Orache) but with much Cakile maritima (Sea Rocket) and Salsola kali (Prickly Saltwort) developed along the seaward edge of the dune ridge.

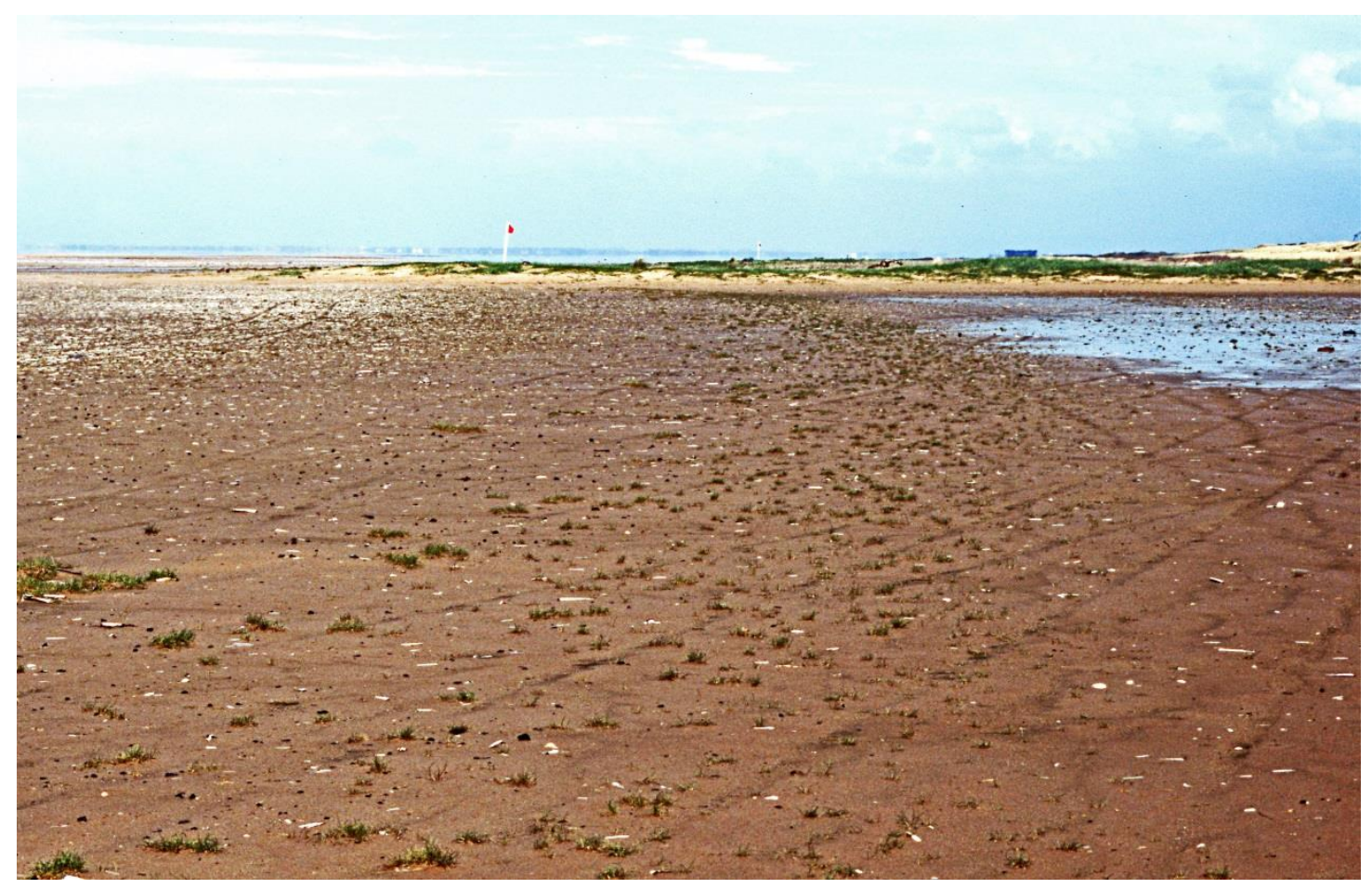

Figure 2. New Green Beach in May 2005 looking north, showing initial colonisation by Puccinellia maritima

Inland of the dune ridge, the original beach plain became waterlogged in wet weather, being flooded in winter with up to $50 \mathrm{~cm}$ depth of fresh-water to form a primary dune-slack with dimensions of $300 \times 30 \mathrm{~m}$, covering an area of 0.7 ha. This usually dried up in early summer. There was a marked change in slack vegetation over the study period. From 2004 to 2006 Puccinellia maritima was dominant, together with typical saltmarsh plants, such as Tripolium pannonicum (Sea Aster), Cochlearia anglica (English Scurvy-grass), Lysimachia maritima (Sea Milkwort), Spartina anglica (Common Cord-grass) and Triglochin maritima (Sea Arrow-grass) in a sparse open sward. By 2006, pioneer dune-slack species were beginning to appear, especially Agrostis stolonifera (Creeping Bent) and Juncus articulatus (Jointed Rush), forming large spreading patches that persisted for several years. In 2007, the third growing season, Bolboschoenus maritimus (Sea 
Club-rush) was present, together with other high-level saltmarsh plants, such as Carex extensa (Long-bracted Sedge), Juncus gerardii (Saltmarsh Rush), J. maritimus (Sea Rush), J. ranarius (Frog Rush), Oenanthe lachenalii (Parsley Water-dropwort), Parapholis strigosa (Hard-grass) and Schoenoplectus tabernaemontani (Grey Club-rush) (Fig. 6). The first Alnus glutinosa (Alder) seedling was noted in that year. Several basiphilous slack species appeared in 2008, including Blackstonia perfoliata (Yellow-wort) Centaurium erythraea (Common Centaury), C. littorale (Seaside Centaury), Isolepis setacea (Bristle Club-rush) and Trifolium fragiferum (Strawberry Clover). Phragmites australis (Common Reed) was identified for the first time, while large patches of Bolboschoenus maritimus became established in the deeper northern section of the slack. Five Salix (Willow) taxa began to colonise the drier slack areas, these increasing to ten by 2019, with $S$. repens predominating. Meanwhile, it was evident that saltmarsh species were declining or disappearing, Puccinellia maritima, for example, not being seen after 2011. Dactylorhiza incarnata (Early Marsh-orchid), D. praetermissa (Southern Marsh-orchid) and Epipactis palustris (Marsh Helleborine) appeared in 2009, together with the first plants of Parnassia palustris (Grass-of-Parnassus).

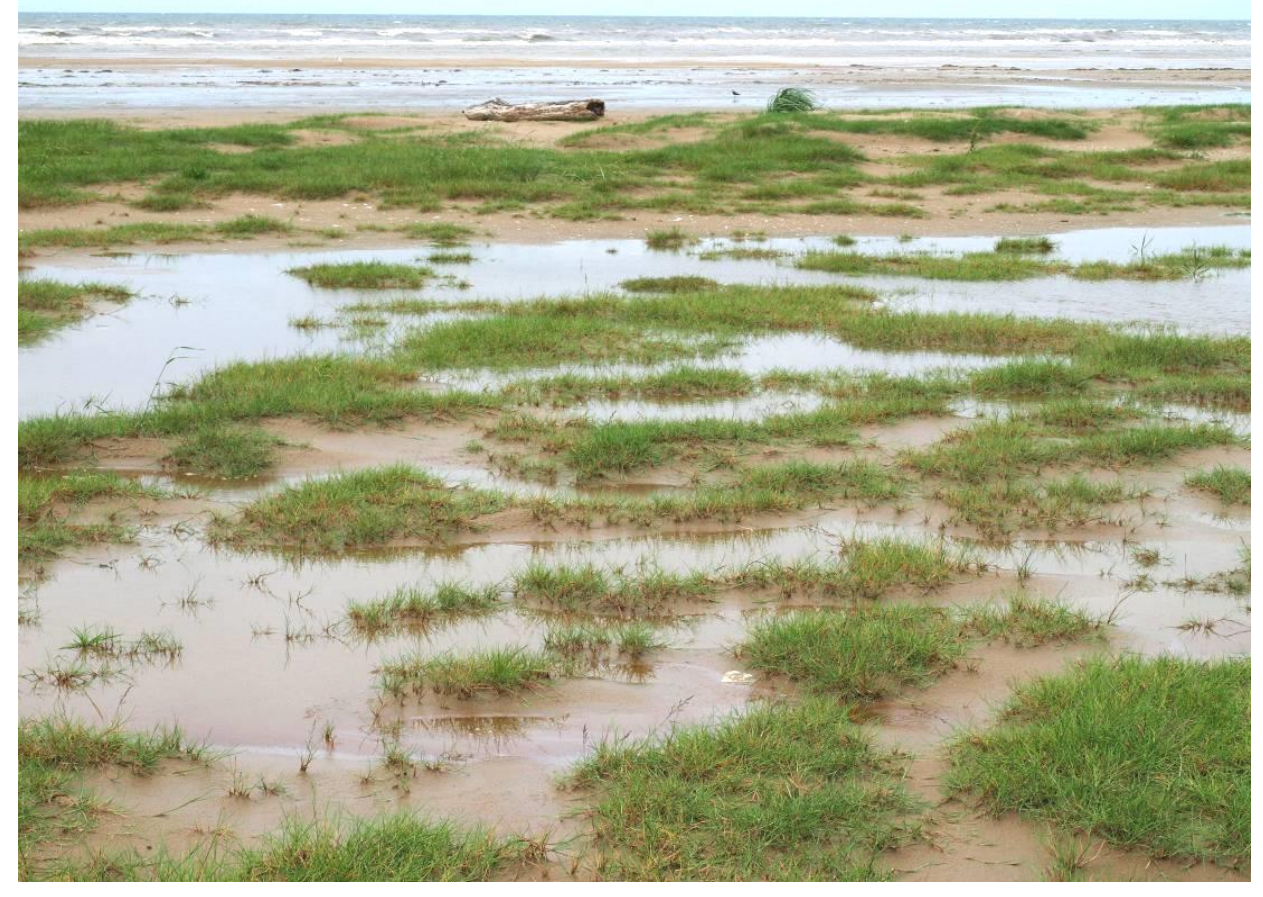

Figure 3. New Green Beach slack in 2007, comprising an open sward of patchy Puccinellia maritima, with incipient dune ridge in background

Although not quantified, it was noted that the initially open vegetation mosaic in the slack quickly closed over time, the amount of bare ground being greatly reduced by 2010, with hardly any present in 2015 . 


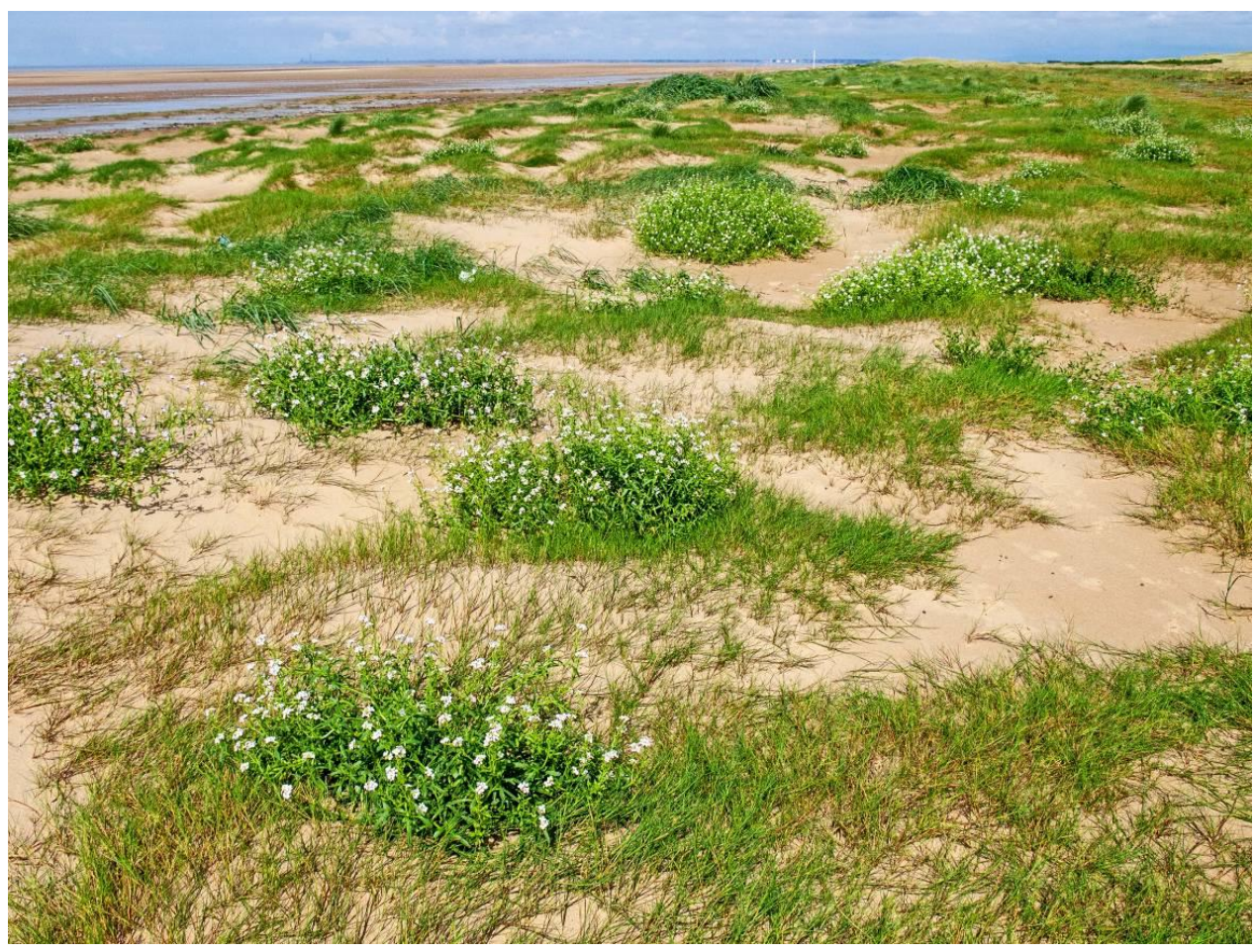

Figure 4. 'Proto-dunes' forming around Puccinellia maritima with Cakile maritima, New Green Beach, September 2008

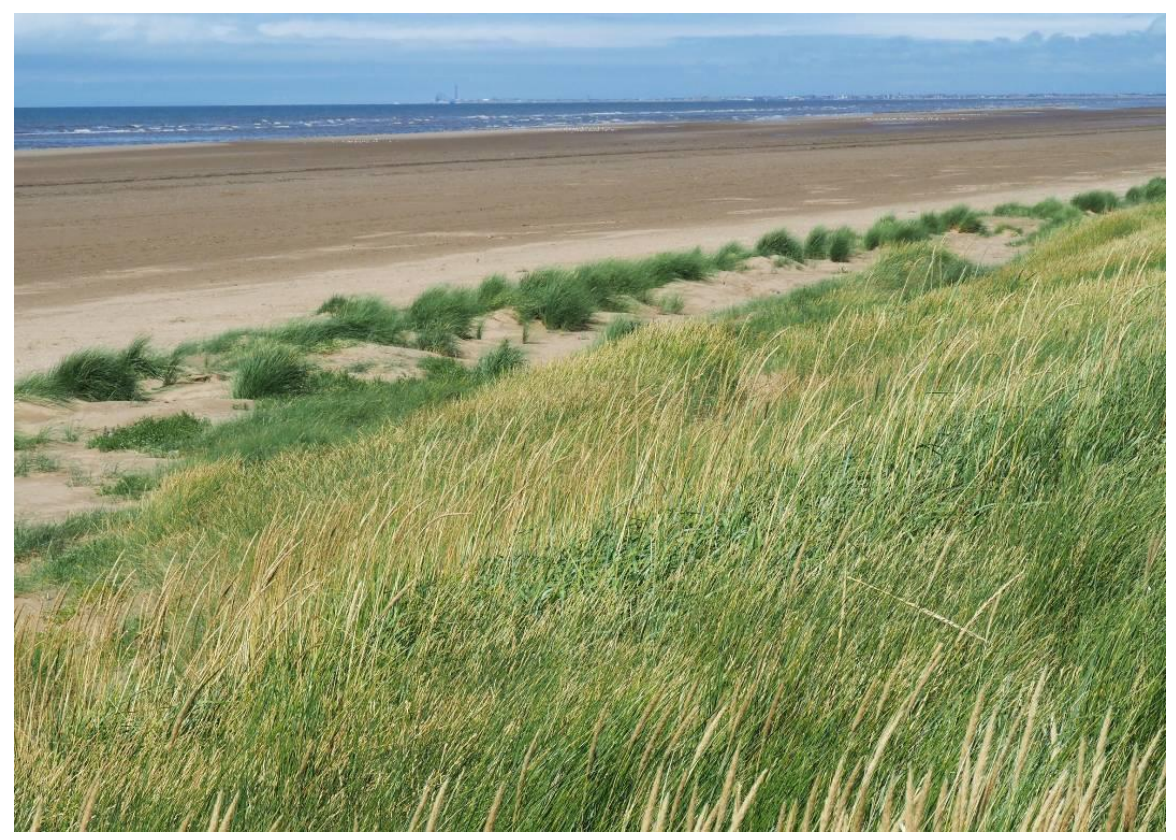

Figure 5. New Green Beach ridge with embryo dune formation, August 2018 


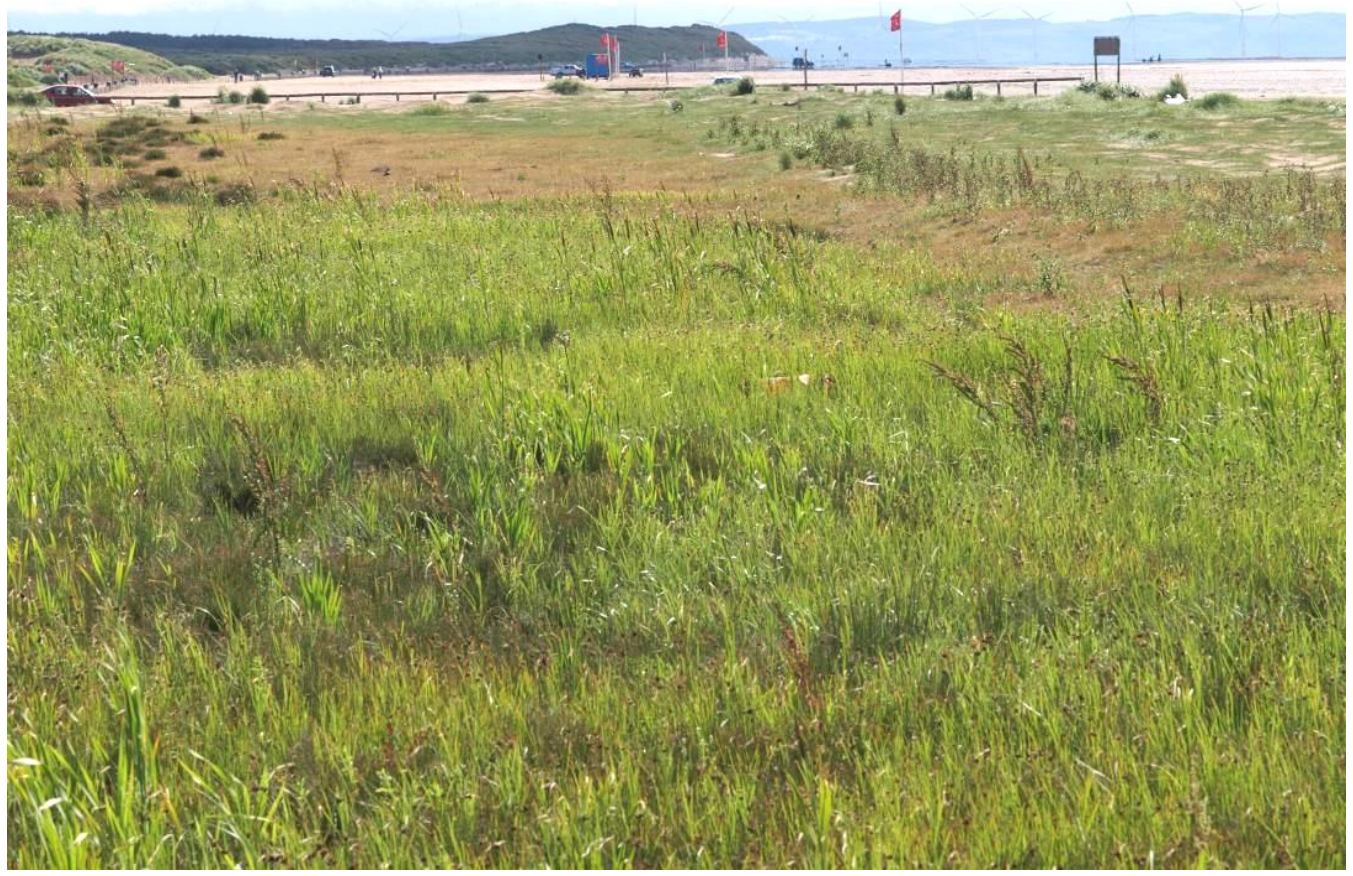

Figure 6. Rapid vegetation development, New Green Beach slack, July 2008

Sand-blow into the western edge of the slack created an intermediate zone 15-18 m wide of dry/damp-slack habitat, supporting a diverse assemblage of sand-dune, saltmarsh, ruderal and dune-slack plants, including much Sagina nodosa (Knotted Pearlwort) and Trifolium fragiferum. After 2008, this zone was colonised by large populations of Dactylorhiza praetermissa, $D$. incarnata, Epipactis palustris, Centaurium littorale and Parnassia palustris, together with occasional patches of Euphrasia spp. (Eyebrights) (Fig. 7).

By 2009, the northern and deeper section of the slack had developed a tall-herb fen, including much Bolboschoenus maritimus, Phragmites australis and Typha latifolia (Bulrush) interspersed with patches of Eleocharis palustris (Common Spike-rush) and E. uniglumis (Slender Spike-rush). Agrostis stolonifera was abundant throughout, joined from 2011 onwards, by a high frequency of Berula erecta (Lesser Water-parsnip) (Fig. 8). 


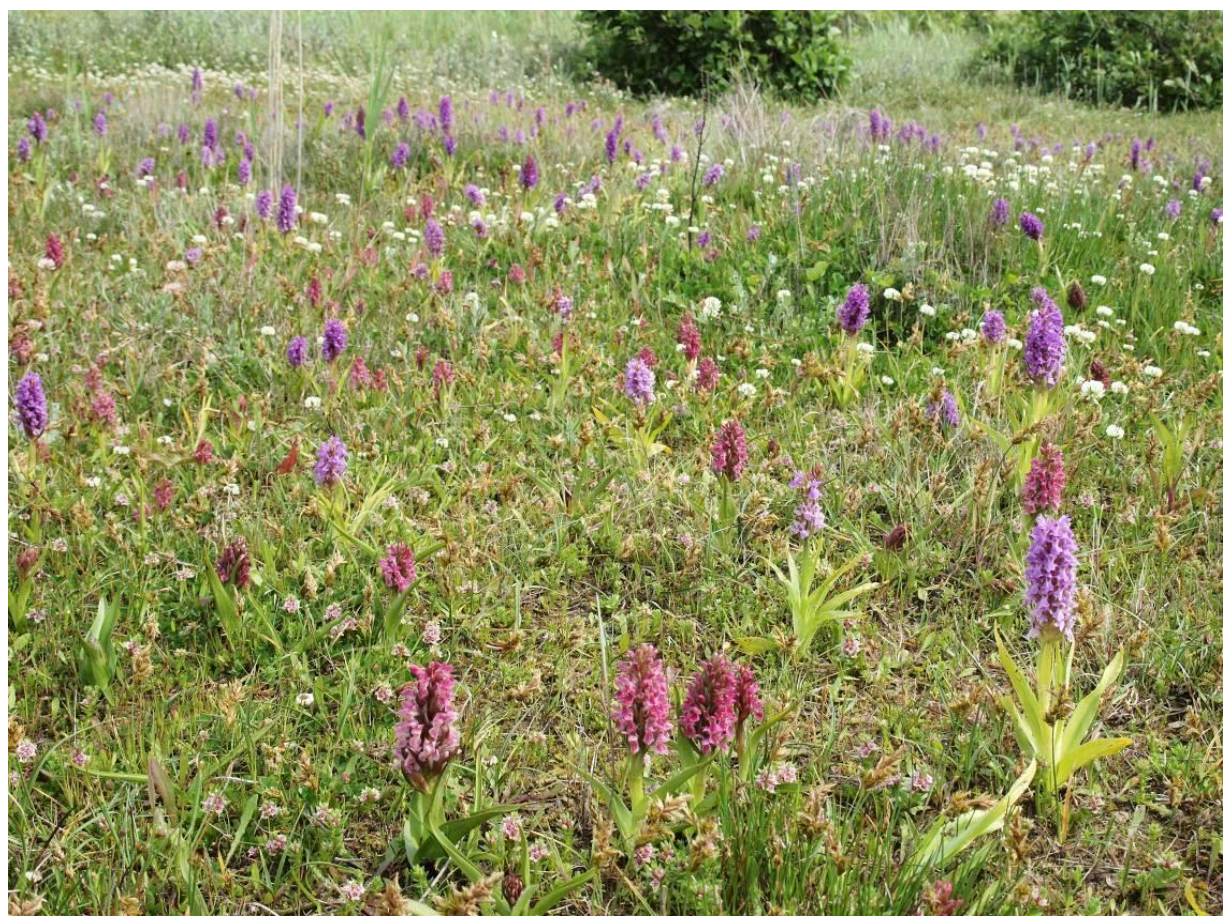

Figure 7. Marsh-orchids on western fringe of New Green Beach slack, June 2017

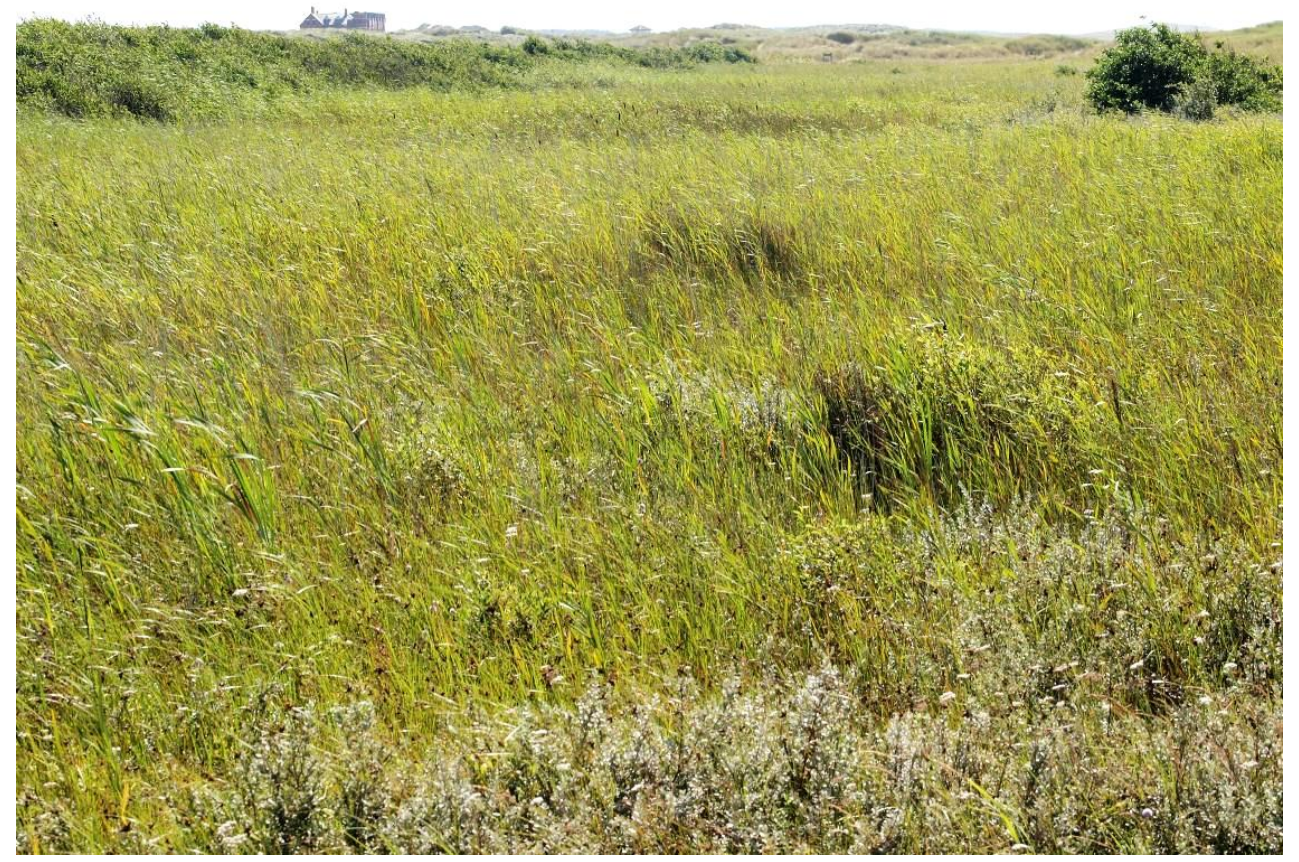

Figure 8. New Green Beach tall-herb fen, August 2017 
A lightly-used informal footpath following the eastern edge of the site supported a variety of plants favouring short vegetation, including Carex viridula (Smallfruited Yellow-sedge), Centaurium pulchellum (Lesser Centaury) and Parnassia palustris. About 4800 flowering individuals of the latter were counted in 2013 during a coastwide volunteer survey of this species, representing one of its largest concentrations on the Sefton Coast (Smith \& Deed, 2019). Subsequently, the footpath population of $P$. palustris declined but was replaced by a great increase in numbers along the western part of the slack, exceeding 10,000 plants in 2017 (Fig. 9).

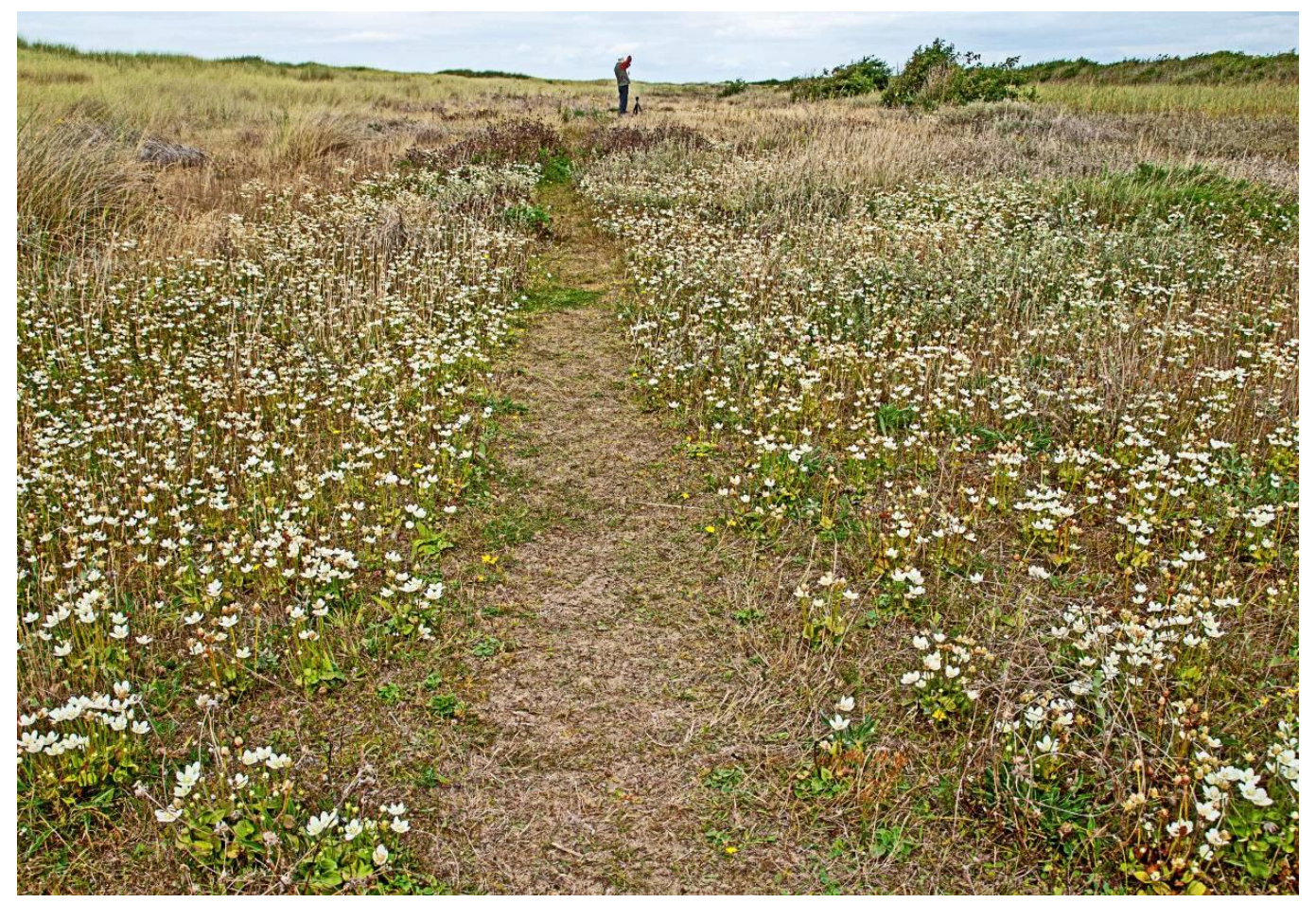

Figure 9. Parnassia palustris, western fringe of the New Green Beach, August 2017

From 2008 onwards, Alnus glutinosa bushes became more numerous along the slack's eastern fringe. By 2017, they were up to $3 \mathrm{~m}$ high, interspersed with occasional large Salix, especially S. caprea (Goat Willow) and S. cinerea (Grey Willow) (Fig. 10).

The only vegetation management during the study period was regular uprooting by volunteers of large numbers of seedling Hippophae rhamnoides (Sea Buckthorn), a shrub that was introduced to this coast in the 1890s and is extremely invasive (Isermann et al., 2007; Smith, 2009, 2020).

Some evidence of rabbit (Oryctolagus cuniculus) grazing was apparent early in the study but, after about 2015, none was seen. 


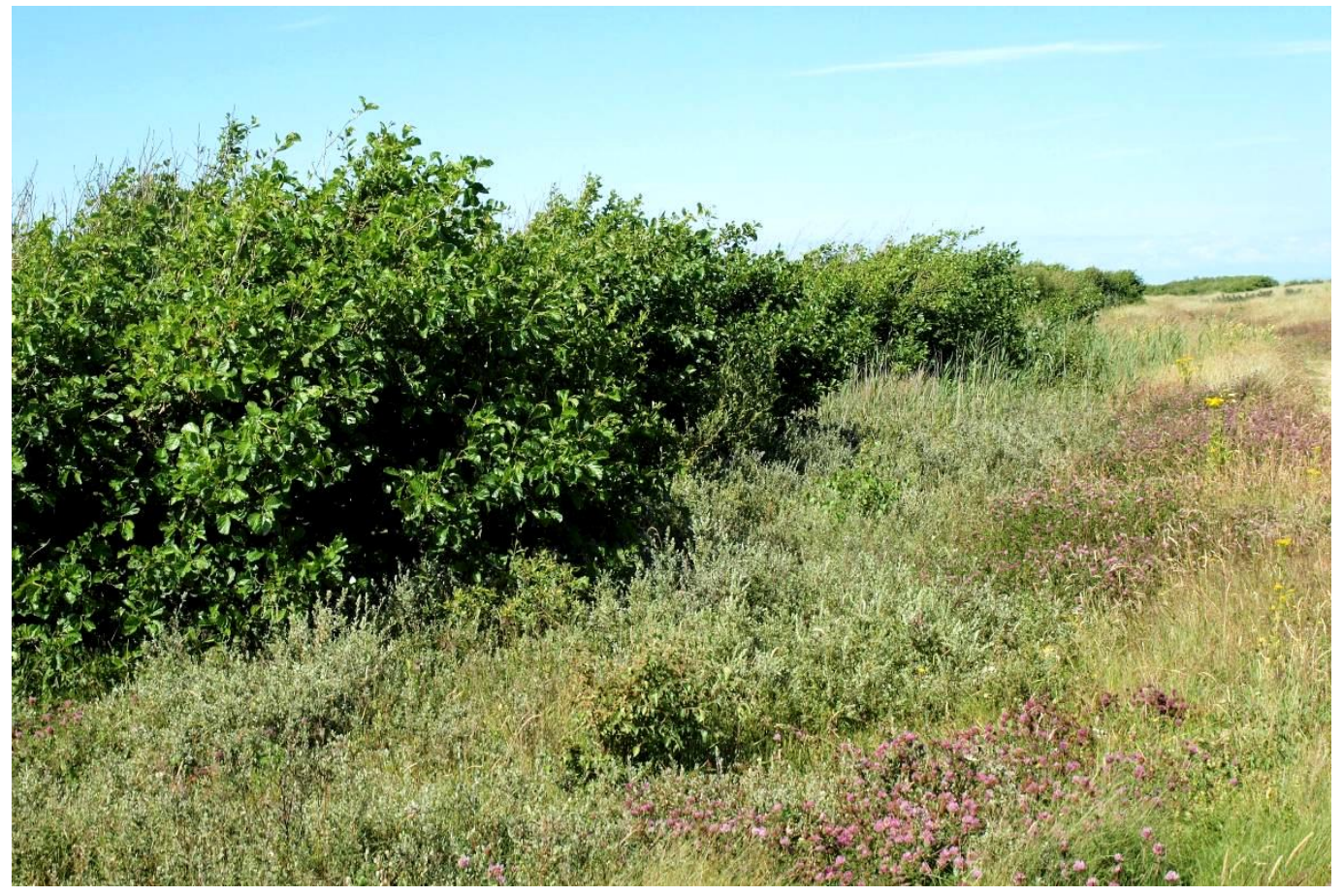

Figure 10. Alnus/Salix carr along the eastern fringe of New Green Beach, July 2017

\section{Vegetation}

Reference to keys and descriptions in Rodwell $(1995,2000)$ indicated that the early slack vegetation resembled the NVC's SM13: Puccinellia maritima saltmarsh but, within a few years, this had evolved into a brackish marsh community with similarities to SM18: Juncus maritimus saltmarsh, though here J. maritimus (Sea Rush) could hardly be described as 'dominant in tall dense clumps' (Rodwell, 2000). After 2009, the northern section of the slack was best regarded as a mosaic of S21: Scirpus (= Bolboschoenus) maritimus swamp, S4: Phragmites australis swamp and reed-beds, S12: Typha latifolia swamp, S19: Eleocharis palustris swamp and SM20: Eleocharis uniglumis saltmarsh, interspersed with SM18. To the south, this graded into one of the younger wet dune-slack communities with much Salix repens, perhaps SD14: Salix repensCampylium stellatum dune-slack (Rodwell, 1995; 2000). The intermediate zone between the dune ridge and slack seemed closest to SD13: Sagina nodosaBryum pseudotriquetrum dune-slack, this being characteristic of early-stage, briefly-wetted slacks (Rodwell, 2000).

The plant communities of the embryo and mobile dunes accorded with SD4: Elymus farctus subsp. boreali-atlanticus (now Elymus junceiformis) foredune and SD6 Ammophila arenaria mobile dune, while the strandline vegetation, when present, was referrable to SD2: Honckenya peploides-Cakile maritima strandline (Rodwell, 2000). 
The strip of immature Alnus/Salix woodland along the eastern edge of the site did not resemble any of the community descriptions (W5-7) in Rodwell (1991).

\section{Analysis of quadrats}

Fifty-two vascular taxa were recorded in the 11 quadrats, those with the highest frequency being Agrostis stolonifera (7 occurrences), Bolboschoenus maritimus (7), Lysimachia maritima (7), Mentha aquatica (Water Mint) (8) and Phragmites australis (9). The number of taxa per quadrat ranged from 7 to 23 with a mean and standard deviation of $14.9 \pm 5.6$ and median 18. Mean vegetation height was $38.1 \pm 21.8 \mathrm{~cm}$, median 33 and had a range of 10 to $70 \mathrm{~cm}$. There was negligible bare ground. Ten (19\%) of the plants identified in quadrats were nationally or regionally notable, eight being Red-listed.

\section{Soil $p H$}

Sub-surface soil pH in the quadrats ranged from 6.9 to 7.5 , with a mean and standard deviation of $7.2 \pm 0.2$ and a median of 7.2.

\section{Plant communities}

TABLEFIT analysis of the quadrats is summarised in Table 1. Samples 1-3 from the southern section of the slack had some accordance with SD15: Salix repensCalliergon cuspidatum (= Calliergonella cuspidata) dune-slack. Otherwise, a variety of dune-slack, swamp and grassland communities was indicated.

However, all the samples provided 'very poor' statistical matches to recognised NVC vegetation types.

\section{Changes in species richness}

By autumn 2019, a total of 246 vascular taxa had been identified on the New Green Beach, only 23 (9\%) being non-native or introduced natives. Wellrepresented genera include Carex (13 taxa), Juncus (8), Salix (11) and Trifolium (7). Forty-one (17\%) of the plants were regionally or nationally notable, $16(7 \%)$ being UK and/or England Red-listed (See Appendix 1 at end of paper).

About $36 \%$ of the total number recorded were primarily sand-dune plants, $42 \%$ typical of dune-slacks and $8.5 \%$ generally associated with the saltmarsh habitat, while about $13 \%$ could be characterised as ruderals. However, these percentages varied considerably over the 15 years of the study. Thus, in 2006, the proportion of saltmarsh plants was 39\%, falling to $4 \%$ in 2019. Meanwhile, freshwater wetland plants increased from $24 \%$ to $69 \%$ of the annual totals during the same period.

Fig. 11 shows species accumulation per year during the study period. This maintained a steady rate of increase up to about 2010 , followed by a gradual reduction in the rate of addition. The number of vascular taxa recorded in each year increased steadily from one in 2005 to a peak of 162 in 2011. Thereafter, numbers tended to level off or even show a small decline (Fig. 12). There was a 
considerable turnover of species. Although the site accumulated 246 taxa, the maximum number present in any one year was 162 . Fig. 13 shows that the number of taxa lost between years tended to increase over time.

Table 1. TABLEFIT analysis of New Green Beach quadrats

No. 1-3: southern section of slack; 4-6: drier western fringe; 7-11: tall-herb fen to the north

\begin{tabular}{|c|c|c|c|c|c|}
\hline No. & $\begin{array}{l}\text { NVC } \\
\text { code }\end{array}$ & Community & Sub-community & $\begin{array}{l}\text { \% } \\
\text { fit }\end{array}$ & Match \\
\hline 1 & SD15 & $\begin{array}{l}\text { Salix repens-Calliergon } \\
\text { cuspidatum (= Calliergonella } \\
\text { cuspidata) dune-slack }\end{array}$ & & 30 & $\begin{array}{l}\text { Very } \\
\text { poor }\end{array}$ \\
\hline 2 & SD15 & $\begin{array}{l}\text { Salix repens-Calliergon } \\
\text { cuspidatum (= Calliergonella } \\
\text { cuspidata) dune-slack }\end{array}$ & & 26 & $\begin{array}{l}\text { Very } \\
\text { poor }\end{array}$ \\
\hline 3 & SD15 & $\begin{array}{l}\text { Salix repens-Calliergon } \\
\text { cuspidatum (= Calliergonella } \\
\text { cuspidata) dune-slack }\end{array}$ & & 24 & $\begin{array}{l}\text { Very } \\
\text { poor }\end{array}$ \\
\hline 4 & SD16a & $\begin{array}{l}\text { Salix repens-Holcus lanatus } \\
\text { dune-slack }\end{array}$ & Ononis repens & 24 & $\begin{array}{l}\text { Very } \\
\text { poor }\end{array}$ \\
\hline 5 & MG12b & $\begin{array}{l}\text { Festuca arundinacea (= } \\
\text { Schedonorus arundinaceus) } \\
\text { grassland }\end{array}$ & Oenanthe lachenalii & 13 & $\begin{array}{l}\text { Very } \\
\text { poor }\end{array}$ \\
\hline 6 & SD13 & $\begin{array}{l}\text { Salix repens-Bryum } \\
\text { pseudotriquetrum dune- } \\
\text { slack }\end{array}$ & & 15 & $\begin{array}{l}\text { Very } \\
\text { poor }\end{array}$ \\
\hline 7 & $\mathrm{~S} 12 \mathrm{~b}$ & Typha latifolia swamp & Mentha aquatica & 17 & $\begin{array}{l}\text { Very } \\
\text { poor }\end{array}$ \\
\hline 8 & S4f & $\begin{array}{l}\text { Phragmites australis reed- } \\
\text { bed }\end{array}$ & $\begin{array}{l}\text { Atriplex hastata }(= \\
\text { A. prostrata)- } \\
\text { Agrostis stolonifera }\end{array}$ & 26 & $\begin{array}{l}\text { Very } \\
\text { poor }\end{array}$ \\
\hline 9 & S20b & $\begin{array}{l}\text { Schoenoplectus } \\
\text { tabernaemontani swamp }\end{array}$ & Agrostis stolonifera & 28 & $\begin{array}{l}\text { Very } \\
\text { poor }\end{array}$ \\
\hline 10 & SD15 & $\begin{array}{l}\text { Salix repens-Calliergon } \\
\text { cuspidatum (= Calliergonella } \\
\text { cuspidata) dune-slack }\end{array}$ & & 23 & $\begin{array}{l}\text { Very } \\
\text { poor }\end{array}$ \\
\hline 11 & S20b & $\begin{array}{l}\text { Schoenoplectus } \\
\text { tabernaemontani swamp }\end{array}$ & Agrostis stolonifera & 30 & $\begin{array}{l}\text { Very } \\
\text { poor }\end{array}$ \\
\hline
\end{tabular}




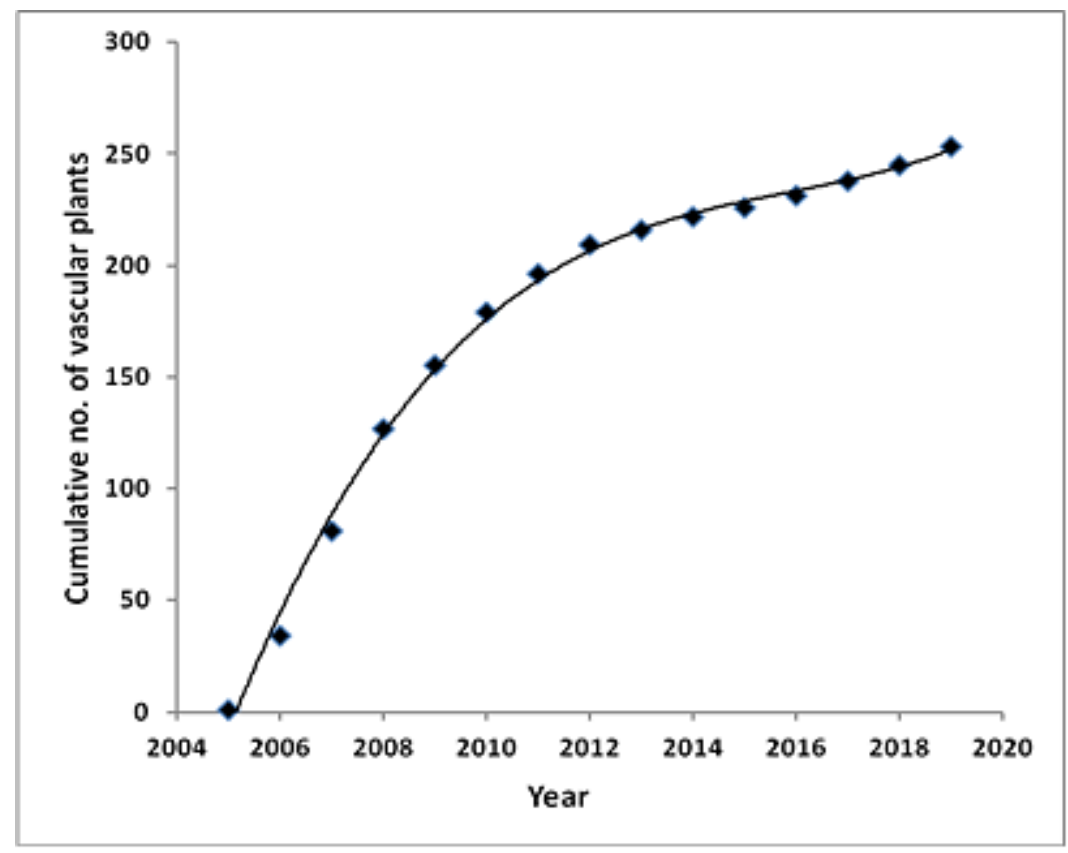

Figure 11. Rate of annual accumulation of taxa on the New Green Beach (2005 - 2019) (fitted line: polynomial)

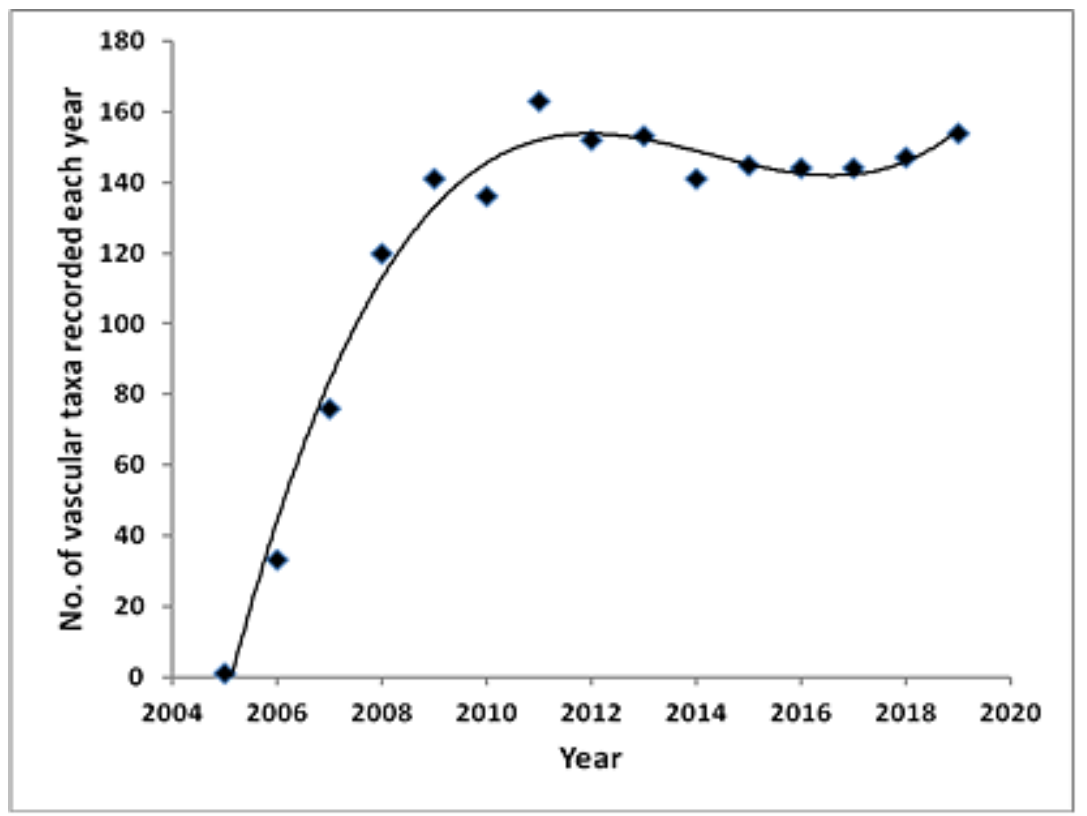

Figure 12. The number of vascular taxa identified in each year of the study (2005-2019) (fitted line: polynomial) 


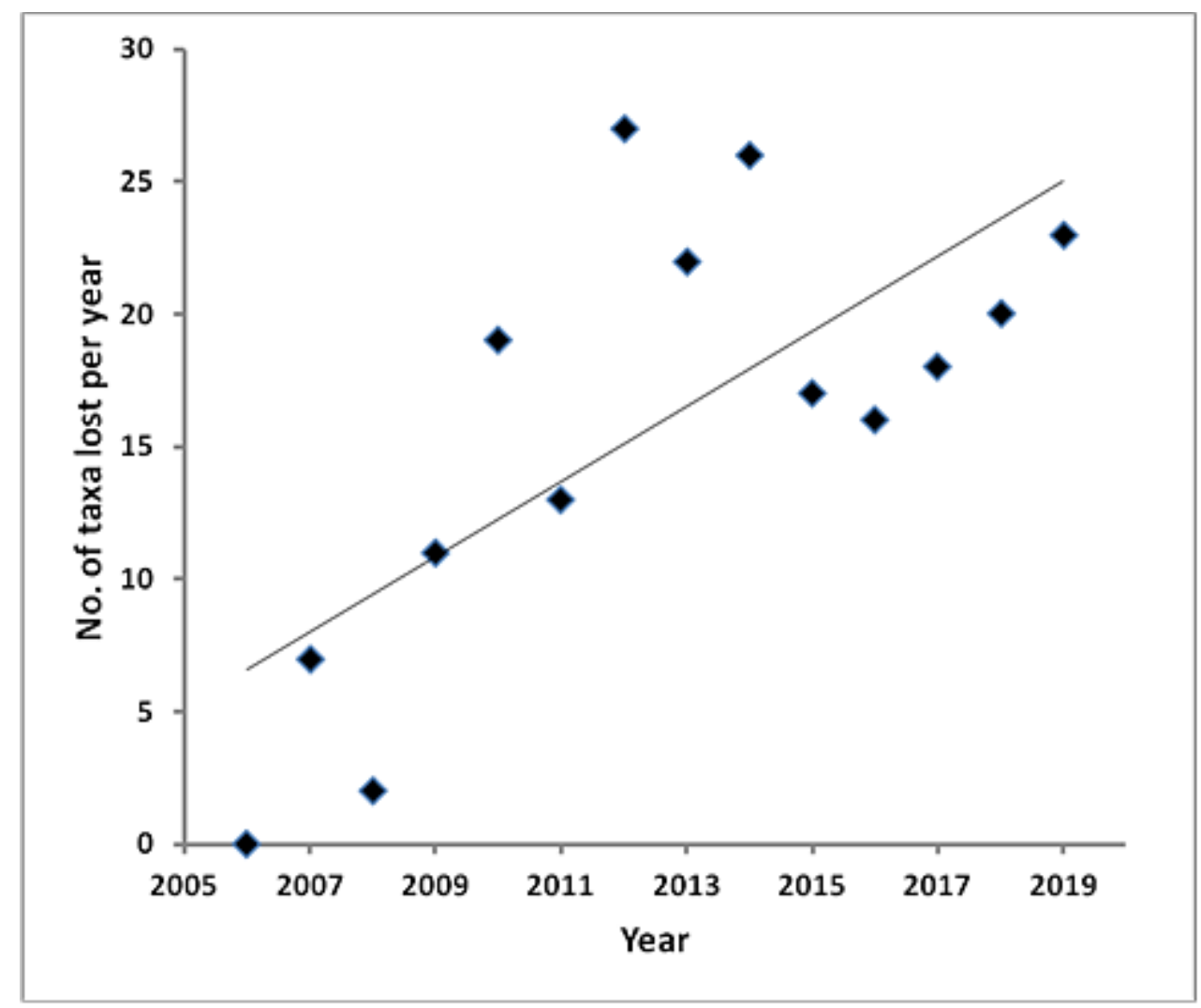

Figure 13. Number of taxa lost each year from 2006 to $2019(r=0.712 ; p=$ 0.0043)

The proportion of plants in different frequency categories changed markedly during the study (Fig. 14). Thus, in 2006, only $3 \%$ of taxa were rated 'abundant', this proportion increasing to over $20 \%$ by 2012 and remaining at about that level subsequently. Species classed as 'frequent' also increased from $0 \%$ in 2006 to about $20 \%$ in 2012, maintaining that level thereafter. The 'occasional' category remained at about $35 \%$ throughout. In contrast, over $60 \%$ of plants were considered 'rare' in 2006, this proportion falling to 20-25\% from 2012 onwards.

\section{Adaptation to salinity}

Mean Ellenberg salinity values initially fell rapidly from 5 in 2006 to 1.1 in 2009, declining more slowly to about 0.8 during the rest of the study period (Fig. 15). A comparison of the frequency distribution of S-values in 2006 with those in 2017 provides further evidence for this trend (Fig. 16). Thus, the maximum value in 2006 was $S=9$ ('species of extremely saline conditions'), represented by three taxa ( $9 \%$ of the total). In contrast, the maximum in 2019 was S = 5 ('species of upper saltmarsh') (1.4\% of taxa), while the latter data are heavily skewed towards $S=0$ ('species absent from saline sites') (Hill et al., 2004). 


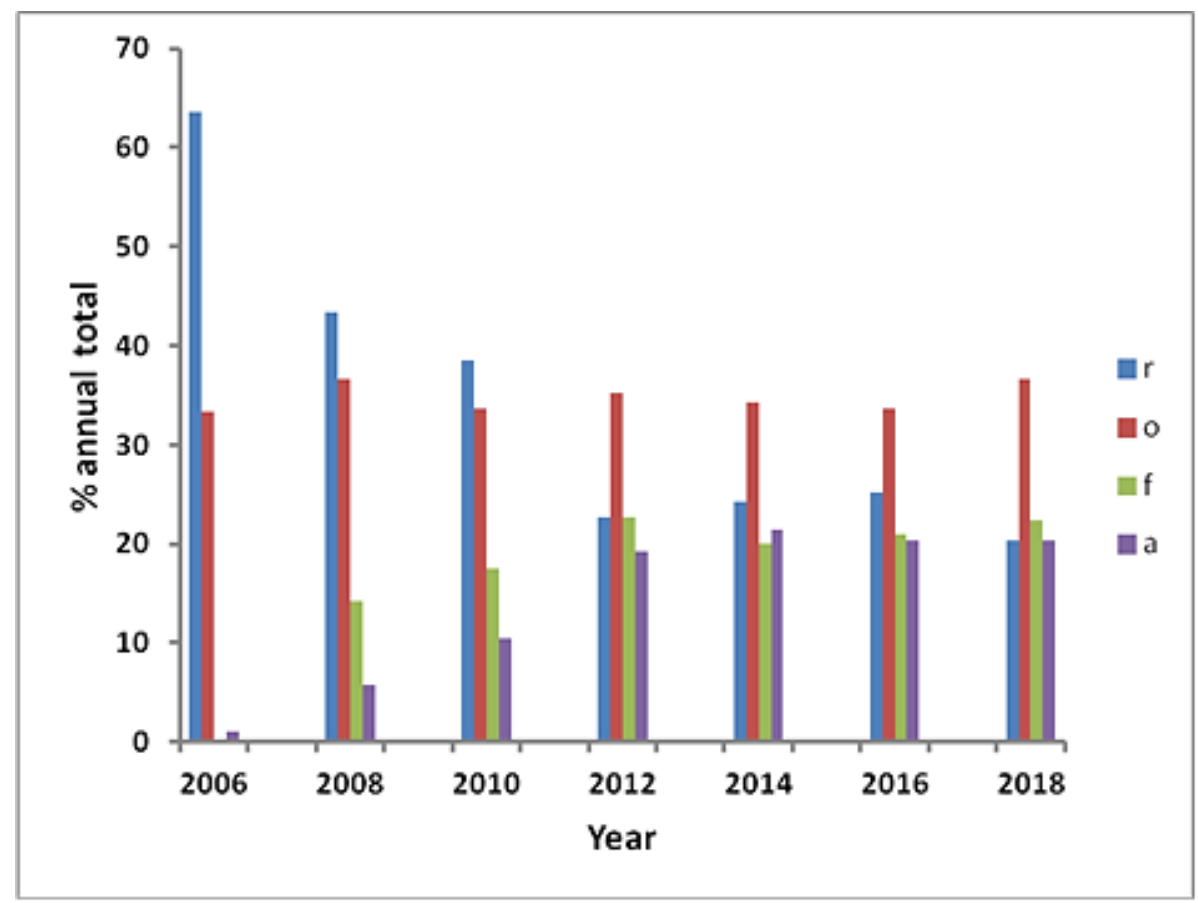

Figure 14. The proportion of vascular taxa in each of four frequency categories in alternate years from 2006 to $2018(r=$ rare, $0=$ occasional, $f=$ frequent, $a=$ abundant)

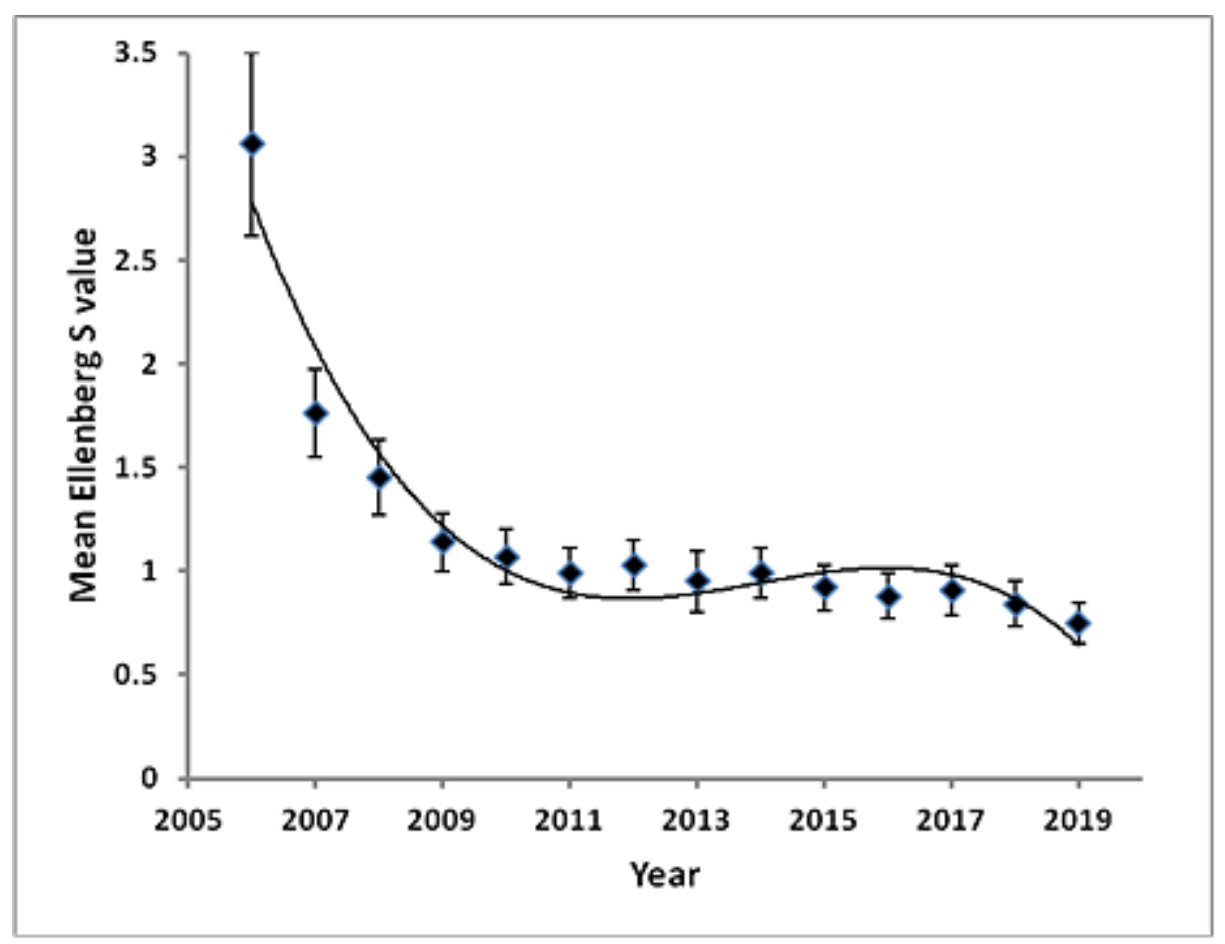

Figure 15. Mean and standard error of Ellenberg salinity value for vascular plants recorded annually from 2006 to 2019 (fitted line: polynomial; r = $0.968 ; p \leq 0.00001)$ 


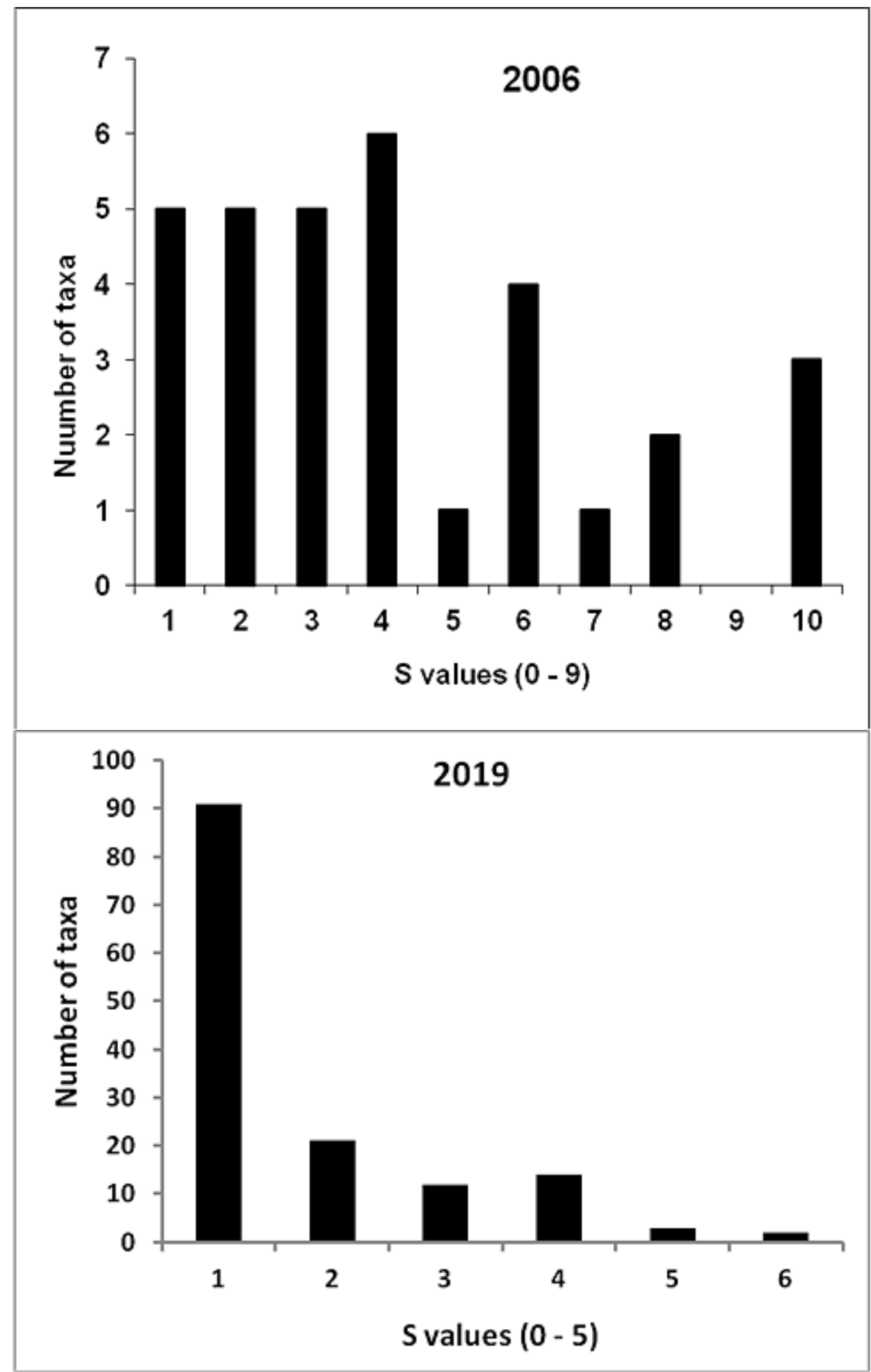

Figure 16. Frequency distributions of Ellenberg salinity-values for vascular plants in 2006 (above) and 2019 (below), showing shift towards nonhalophytes 


\section{Adaptation to soil fertility}

There was a declining trend of mean Ellenberg $\mathrm{N}$-values for vascular plants recorded in each year from 2006 to 2019, from 5.8 to about 4.8 (Fig. 17). This indicated adaptation to sites of intermediate fertility, tending towards more infertile conditions (Hill et al., 2004). There was some indication of a levelling off in the trend latterly.

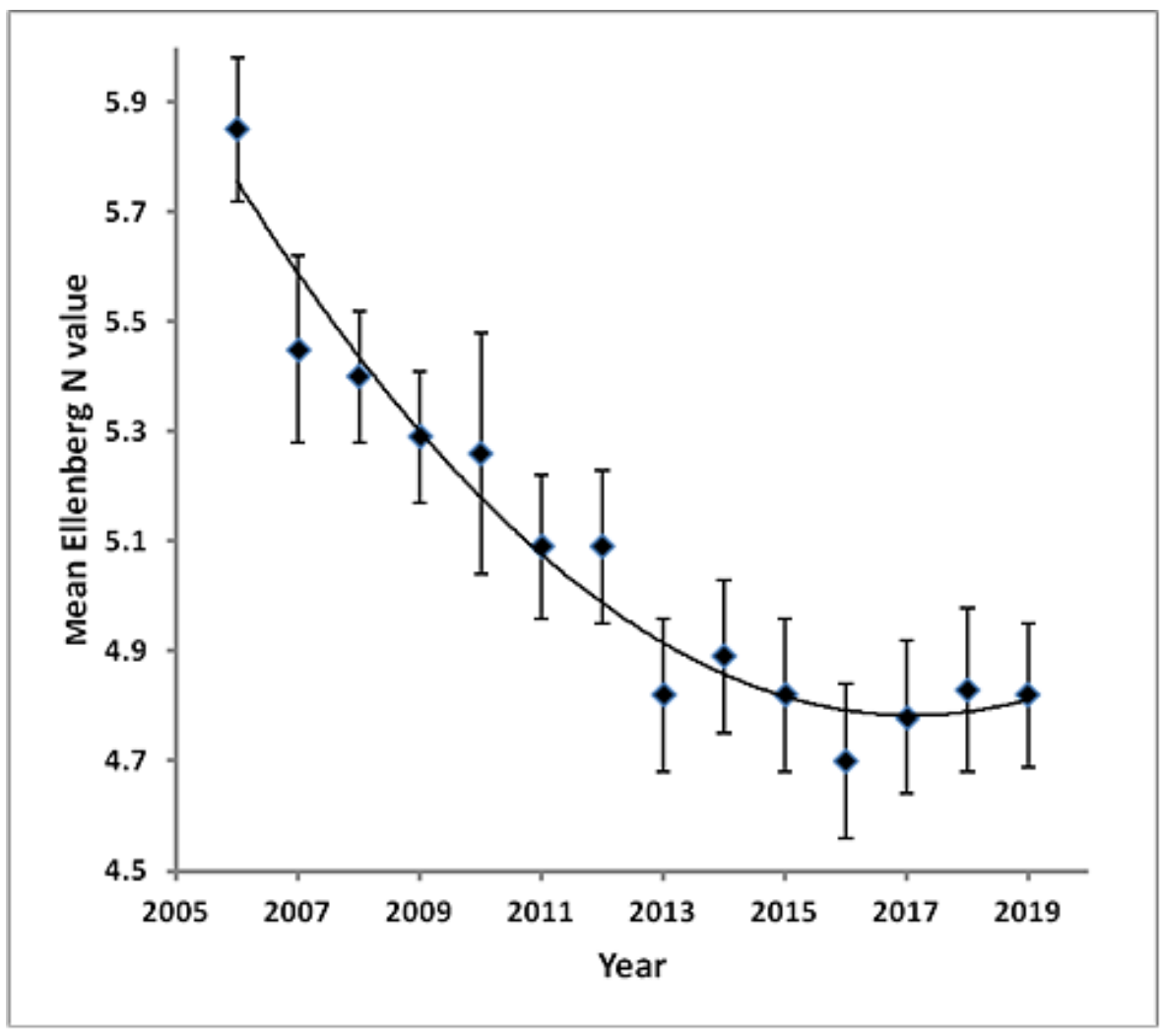

Figure 17. Mean and standard error of vascular plant Ellenberg $\mathrm{N}$-values from 2006 to 2019 (fitted line: polynomial; $r=-0.977 ; p \leq 0.00001$ )

\section{Adaptation to moisture}

A declining trend of mean Ellenberg moisture $(F)$ values was found from about 6.8 to 6.2 (Fig. 18), indicating progressive adaptation of plants towards soils of average moisture content from constantly damp soils (Hill et al., 2004).

\section{Adaptation to environmental acidity}

Most of the vascular plants recorded on the New Green Beach were adapted to weakly acid to weakly basic conditions, with Ellenberg Reaction (R) values of 6 or 7. A small proportion was typical of more basic (calcareous) conditions $(R=8)$ or of moderately acid soils ( $R=4$ or 5 ) (Hill et al., 2004). Fig. 19 shows a trend of falling mean R-values over time, from about 7 in 2006 to 6.4 in 2019. 


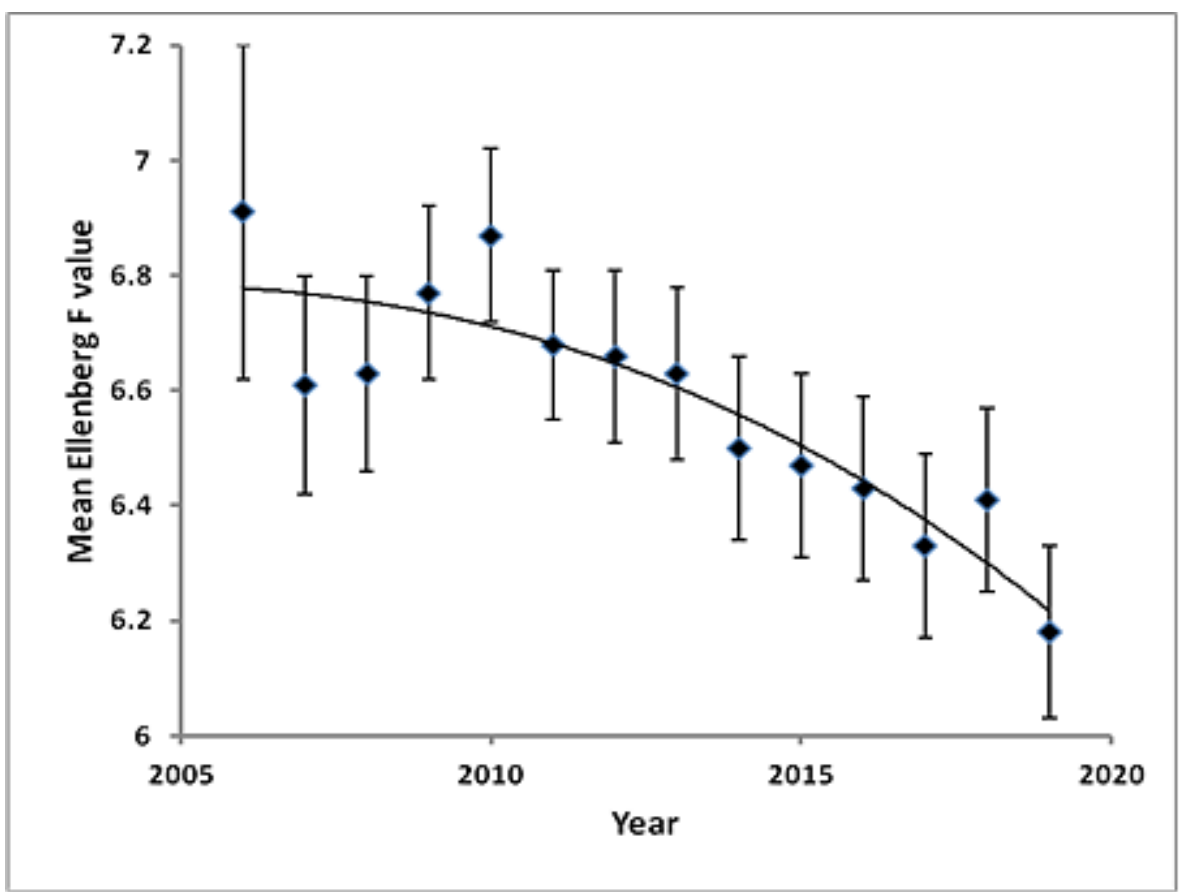

Figure 18. Mean and standard error of vascular plant Ellenberg F-values from 2006 to 2019 (fitted line: polynomial; $r=-0.889 ; p=0.00002$ )

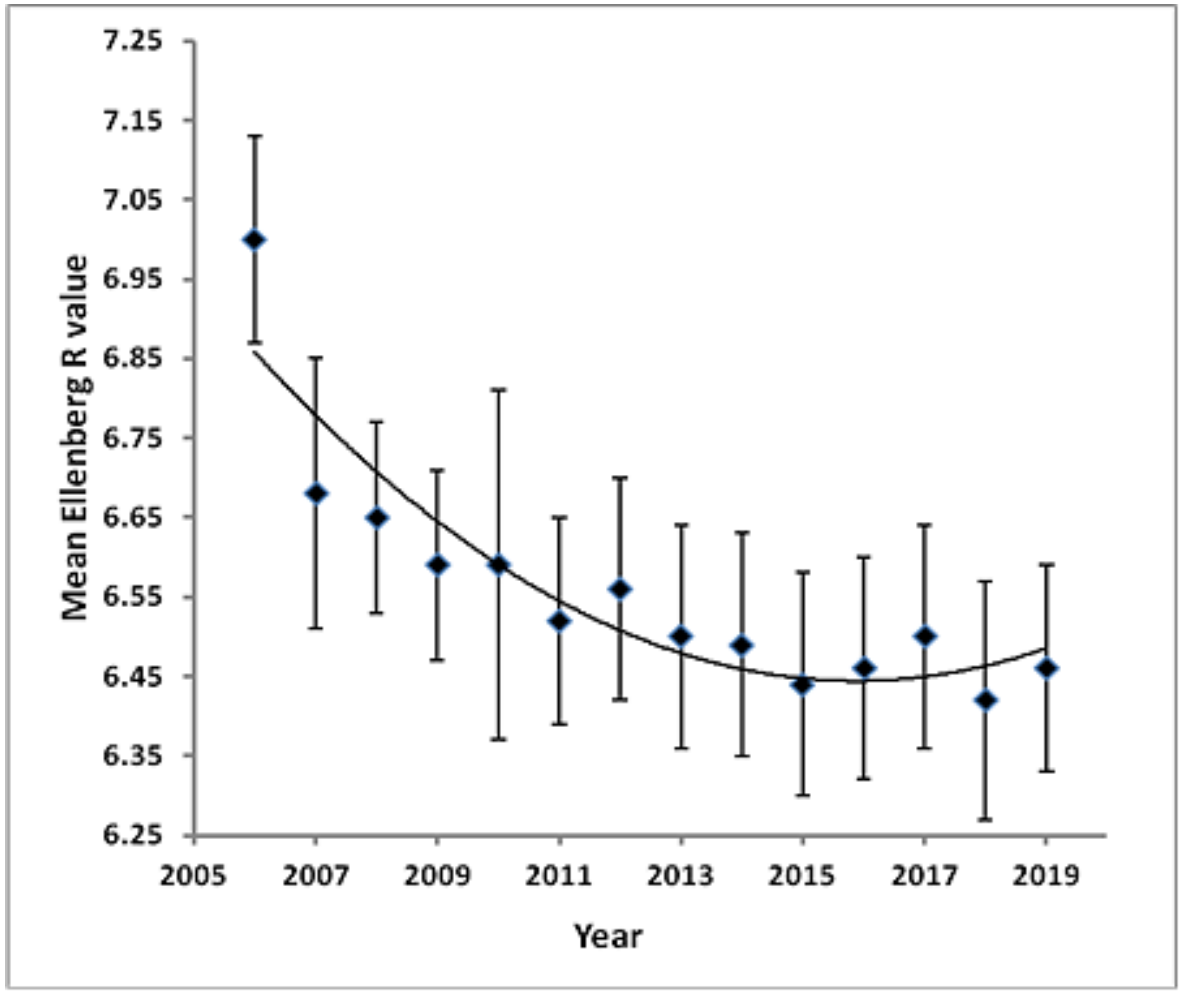

Figure 19. Mean and standard error of vascular plant Ellenberg R-values from 2006 to 2019 (fitted line polynomial; $r=-0.915 ; p \leq 0.00001$ ) 


\section{Discussion}

\section{Green Beach origins}

The term 'green beach' (or 'groene stranden ') seems to have been first used by Westhoff in 1961, cited in Van der Maarel (1977). He described it as a special feature of the Delta region of The Netherlands, being large, elevated beaches mostly situated on estuaries and usually sandy but with silt deposited at lower elevations. There, the green beaches were densely vegetated, consisting of a mosaic of saltmarsh, wet and dry communities, often including embryo dunes with Elymus junceiformis. In north Germany these features were also known as 'beach meadows' (Hansen, 2009; Riediger, 2009). They usually formed in sheltered positions behind dune ridges. Riediger described how the flooding tide lost power on the wide stretches of beach, arriving at the beach meadows with a reduced flow velocity, thereby enabling plants to become established. According to Koppenaal (2007), groene stranden on German and Danish coasts were usually considered to be the first stage in saltmarsh formation, though some developed into dune slacks due to freshwater seepage from dunes behind the beach. This process was also influenced by siltation rate, a higher elevation above mean high-water being associated with slack, as opposed to saltmarsh development. Connolly (2006) reported that beach levels between Birkdale and Ainsdale rose by about $0.5 \mathrm{~m}$ between 1981 and 2002 at an average annual rate of $2.4 \mathrm{~cm}$. This high rate of siltation probably played a major role in the observed vegetation changes in the present study, though Connolly suggested that restrictions in beach car-parking from 1993 also contributed.

The rapid development of the New Green Beach began with embryo dunes formed around Puccinellia maritima rather than the more typical Elymus junceiformis. Such dune initiation is not mentioned in standard texts (e.g. Maun, 2009; Packham \& Willis, 1997; Ranwell, 1972). However, Heykeyna (1965) described $30 \mathrm{~cm}$-high dunes accreting around $P$. maritima tufts on high-level beaches in north Germany and Denmark, where the power of the flood-tide was reduced. In areas with more blowing sand, these developed into E. junceiformis dunes.

The seasonally-flooded wetland on the New Green Beach is effectively a primary dune-slack or 'swale', formed between two successive sand-dune ridges and dependent upon the local water-table, itself linked mainly to precipitation, especially in winter (Davy et al., 2006). This is a rare slack type on the Sefton Coast, most having formed secondarily by wind erosion of dunes (Smith, 2006; 2009). An early account of what appears to be a similar feature was Wheldon \& Travis's (1923) 'halophytic dune pan'. They described this as 'a commencing slack' in a valley behind the first rampart of dunes between Formby and Birkdale, where halophytes or semi-halophytes included such species as Apium graveolens (Wild Celery), Bolboschoenus maritimus, Carex extensa, Juncus maritimus, Oenanthe lachenalii and Tripolium pannonicum. The halophytic element was lost with time, the last species to disappear being J. maritimus. They remarked that 
the presence of saltmarsh species was attributable to the comparatively low outer dune rampart, thereby allowing free access to spray from the sea.

Earlier, Travis (1916) reported on a vegetation transition between a sandy shore and saltmarsh at Ainsdale in 1911, where dunes were rapidly advancing seawards, as is occurring today. Early colonists were Agrostis stolonifera, together with $T$. pannonicum and other saltmarsh plants. These were later joined by Juncus articulatus, J. bufonius, Sagina nodosa, etc., in a rich flora which gained a rapid foothold in less than 12 months. By the following year, 16 additional vascular taxa had appeared in the slack, Salix repens already being present. However, saltmarsh species were beginning to disappear. These trends and their rapidity are similar to those described on the New Green Beach.

A comparable feature south of Ainsdale in the early 1930s was described by Allen (1932) as a 'sea-beach flora'. It comprised three parallel strips of $P$. maritima which reached a total length of about $400 \mathrm{~m}$ over about two years. Also present was 'an uprising of regular little hillocks' around $10 \mathrm{~cm}$ high and up to $1.5 \mathrm{~m}$ in diameter, seemingly corresponding to the 'proto-dunes' described in the present study. In the 1931/32 winter, it was observed that the first and second strips of vegetation were separated by a 'large pool of practically fresh water'. Thirty-three vascular plants were identified, these being a mix of saltmarsh, freshwater and ruderal species similar to those on the present-day New Green Beach. However, this formation was soon washed away by winter high-tides.

Such features accord with the 'Type A' slack of Davy et al. (2006), this being a seaward, young dune-slack, potentially subject to brackish conditions. Ranwell (1972) described these coastal slacks as transient features, liable to seawater flooding or to obliteration by embryo-dune growth. As at Ainsdale, they contained, initially, open communities of scattered strandline plants and a few saltmarsh species tolerant of well-drained soils. He also mentioned that, later on, clones of halophytic and wet-slack perennials closed up to form a mosaic which had been little studied, particularly in respect of the persistence of halophytic elements. Riediger (2009) also described small-scale vegetation mosaics, including non-halophytes and dune plants, becoming established on north German beach meadows.

\section{Abiotic variables}

Based on the studies of M.E. Gillham, Ranwell (1972) stated that apparent nonhalophytes could, for a time, tolerate surprisingly high salinities of up to the equivalent of full-strength seawater, without apparent harm to growth. The progressive dominance of non-halophytes at the New Green Beach, despite occasional immersion by high-spring tides, supports this finding. Maun (2009) pointed out that the salt concentration of coastal sandy soils was too low (0.003$0.28 \%$ ) to influence the growth of plants because all species were capable of withstanding up to about $1 \%$ salinity in the substrate. He emphasised that saltspray events and marine inundation were seasonal, occurring mainly in autumn and winter when plants are dormant and that salt was readily leached away by 
rainfall. Therefore, many species of the coastal strand were salt-tolerant nonhalophytes. His findings are consistent with the eventual low proportion of halophytes at the New Green Beach. A reduction in halophytes during dune-slack succession was also reported by Smith (2006) in the adjacent Birkdale frontal dunes. Over a 20-year period, out of eight typical saltmarsh plants initially present, four disappeared, three declined in frequency and only one (Bolboschoenus maritimus) increased.

The decline in mean Ellenberg indicator values for nitrogen during the study period was unexpected, as slack soils, in particular, have been shown to become more eutrophic over time, with aerial deposition of nitrogen possibly contributing to this trend (Grootjans et al., 1998). Thus, during a 17-year study of a beach plain enclosed by a sand-dyke at Schiermonnikoog in The Netherlands, Olff et al. (1993) found that soil nitrogen increased from 7 to $50 \mathrm{~g} \mathrm{~m}^{-2}$, the nitrogen being almost entirely confined to a surface organic matter layer. Similarly, Jones et al. (2010) recorded high rates of nitrogen accumulation in wet habitats at Newborough Warren, although this rate did not increase with age and the soils were much older (about 20-60 years) than those on the New Green Beach. They showed that the most rapid period of soil development commenced when full vegetation cover was established. Page (2018) analysed soil samples from Birkdale Green Beach slacks that were 0, 6, 12, 17, 25 and 30 years old, showing that $\mathrm{N}, \mathrm{P}$ and $\mathrm{K}$ increased over time from an initially low level. However, the rate of increase for nitrogen $\left(0.78 \mathrm{~g} \mathrm{~m}^{-2} \mathrm{yr}^{-1}\right)$ was considerably slower than that reported by Olff et al. (1993) (2.98 $\left.\mathrm{g} \mathrm{m}^{-2} \mathrm{yr}^{-1}\right)$. At the New Green Beach, it is likely that the upper shore was initially enriched with nitrogen-containing material deposited on strandlines (Page, 2018). The nitrogen was then gradually washed out of these young soils by water-table fluctuations. It may be that insufficient time had passed for organic matter to accumulate, thereby increasing the nitrogen pool as described by Sival \& Grootjans (1996). The latter suggested that regular supplies of acid-buffering compounds, mobilised from calcium-rich soil layers by fluctuations in the water-table, slowed down the rate of organic matter accumulation in calcareous dune-slacks, such as that studied here. This idea is supported by Page's (2018) finding of no significant increase in soil organic matter content over his Green Beach chronosequence.

The declining trend of mean Ellenberg moisture values in the study area may be partly due to variations in annual or seasonal rainfall. Thus, Clarke \& Sanitwong Na Ayutthaya (2010) suggested that, due to climate change, a drastic long-term decline in Sefton Coast ground water levels was highly likely. In the shorter-term, accumulation of blown sand in the slack over time would tend to increase the level of the ground surface relative to the water-table, resulting in a gradual drying out of the slack and associated changes in the plant community (Smith, 2009).

Freshly deposited Sefton dune sand is highly calcareous, containing 4-8\% calcium carbonate derived from abundant shell fragments (James, 1993). It is well established that calcareous duneland soils lose their calcium over time and 
become more acidic. Thus, Salisbury (1925) reported a pH decline from 8.2 to 6.4 in about 200 years on the Southport, Merseyside, dunes; changes that were attributed to leaching of calcium carbonate. Crawford \& Wishart (1996) found an even more rapid fall in dune-slack soil pH at Tentsmuir, Scotland, from 7.8 to 6.1 in 53 years. A strong correlation was established by Sýkora et al. (2004) between acidification, organic matter accumulation, soil enrichment and age in an 85-year slack chronosequence at Terschelling in The Netherlands. They regarded acidification as one of the main underlying soil processes. Similarly, Olff et al. (1993) found that the $\mathrm{pH}$ of the upper soil layers on two out of three beach plain habitats decreased from about 8 to 6.5 during their 17-year study. The decline of mean Ellenberg R-values from 7 to 6.5 over 11 years at the New Green Beach parallels these findings. However, this change is small, perhaps because of buffering compounds derived from calcareous ground-water fluctuations discussed by Sival \& Grootjans (1996). In contrast, Page (2018) measured a soil $\mathrm{pH}$ increase over time from a mean of 7.0 to 8.1 in his Birkdale Green Beach slack study. This unexpected result was tentatively attributed to influxes of baserich drainage water and seepage from calcareous dunes to the east, together with occasional large shellfish wrecks contributing calcium carbonate to the oldest sections of Green Beach.

\section{Ecological succession}

The number of vascular taxa recorded each year on the New Green Beach increased rapidly, followed by a levelling off or even a small reduction in speciesrichness (Fig. 12). General models of ecological succession (e.g. Odum, 1971) predict an initial increase in species number over time. Thus, Smith (2006) found that the number of vascular taxa in 26 Birkdale frontal dune-slacks, adjacent to the present study area, increased from 150 to 213 in 20 years. Most of the slacks were about 10 years old at the beginning of his study. Similarly, Smith (2017) reported an increase in species-richness from 16 to 160 vascular taxa over a 12 year period in a large recently-formed secondary dune-slack at Ravenmeols on the Sefton dunes. Isermann (2011) suggested that species richness in a dry dune succession on the German island of Spiekeroog followed a 'hump-back' model, her chronosequence showing, an increase at first, followed by a relatively constant level or a decrease in species number during the later stages of succession. Jones et al. (2010) found a similar trend for dry dunes at Newborough Warren, North Wales, but the species-richness of dune-slacks showed no apparent relationship with successional age for a 100-year chronosequence. They suggested that factors other than age, in particular the water-table regime and grazing had a greater influence on the numbers of plants in calcareous dune-slacks.

In 2019 , its $15^{\text {th }}$ year, the 2.9 ha New Green Beach supported 154 vascular taxa, 106 being recorded in the wetland. The species-richness of early successional stage dune habitats is known to be high (Ranwell, 1972). Thus, as noted earlier, Smith (2006) identified 150 vascular plants in 26 secondary slacks 
at Birkdale that were then only about ten years old. Koppenaal (2007) reported finding 115 species on Dutch green beaches, while Crawford \& Wishart (1966) recorded 142 plants in slacks at Tentsmuir. In contrast, Hansen (2009) found only 29-58 species on East Friesian Island beach meadows.

The present study noted systematic changes in the relative frequency of taxa over time (Fig. 14), the proportion of 'rare' species declining, while percentages of 'abundant' taxa increased. A possible explanation is that, initially, many pioneer colonists will tend to occur at low frequency; some will be lost, others becoming established and more dominant in the communities. Also, as the vegetation closes and competition increases, there will be fewer opportunities for new species to enter the sward (Fig.13), these being recorded at first as 'rare'.

Extensive stands of competitive perennials became well established in the New Green Beach slack within about four years, including especially Bolboschoenus maritimus, Phragmites australis and Typha latifolia, forming tallfen vegetation. Such stands are also prevalent in the central and northern parts of Birkdale Green Beach (Smith, 2007), perhaps reflecting a build-up of nitrogen in older slack soils as described by Olff et al. (1993) and Page (2018). Thus, both $B$. maritimus and $T$. latifolia have Ellenberg $N$ (nitrogen) values of 7 , indicating adaptation to richly fertile conditions. Developing for over a decade, these stands may have eliminated some of the lower-growing, less competitive, species, thereby accounting, in part, for the levelling-off in the number of vascular taxa recorded after 2010 (Fig. 12).In a study of dune slacks in Belgium and northwest France, Bossuyt et al. (2003) found that cover of competitive perennials increased after 15 years but pioneer plants persisted until about 50 years, when cover of the competitive species became too high and species-richness declined. Olff et al. (1993) also noted an increase in tall rhizomatous monocots, such as $B$. maritimus and $P$. australis, towards the end of their 17-year study period, while Page (2018) recorded an increase in mean vegetation height from about $10 \mathrm{~cm}$ to $120 \mathrm{~cm}$ in his 30-year Green Beach slack chronosequence. Packham \& Willis (1997) considered $P$. australis was 'a very formidable competitor' under damp conditions of low salinity. A much smaller, Green Beach feature at Tagg's Island, Birkdale (Grid reference: SD313155), which began to form in 1974, supported a dense bed of $P$. australis within 17 years (personal observations). Blanchard (1952) described fen vegetation dominated by large rhizomatous herbs, such as Schoenoplectus (Club-rush), Typha, Carex and Equisetum (Horsetail) at Massam's Slack, a large primary dune slack situated about $3 \mathrm{~km}$ south of the New Green Beach. At the time of her study, this slack was about 50 years old, having developed from an enclosed beach plain. Blanchard also noted a relationship between vegetation type and period of submergence, 5-8 months of annual flooding leading to fen, while drier fringes supported Salix repens associations. This pattern is similar to the New Green Beach slack, where tallherb fen formed in the deeper parts, $S$. repens being more prevalent in the shallower zones. She also recorded the persistence of some single-species 
dominated stands, as at the New Green Beach. The Massam's Slack patches were still present 20 years later, when mapped by Robinson (1971).

Colonisation by Alnus glutinosa and larger Salix spp. on the eastern fringe of the New Green Beach produced a linear wet-woodland or carr habitat similar to that which formed on the older sections of Birkdale Green Beach from 1998 (Smith, 2007). Within ten years, the latter supported parallel lines of $A$. glutinosa trees up to $3 \mathrm{~m}$ high, extending for $2.2 \mathrm{~km}$ and covering an area of about 1.85 ha, the origin of these trees being apparently due to seeds washing up and germinating on a sequence of past flood- or strand-lines (Kristiansen, 2008, McVean, 1956).

The rate of primary succession on the New Green Beach, especially in the wetland, seemed remarkably high, with mature dune-slack, fen and Alnus/Salixcarr habitats becoming established in under a decade from an unvegetated beach-plain. In a study of Section 41 bryophytes Callaghan (2021) also described 'an astonishing rate of vegetation succession' on the southern Green Beach, accounting for an $89 \%$ loss between 2013 and 2020 of $10 \mathrm{~m}$ grid cells occupied by the nationally rare boreal moss Bryum warneum (Sea Bryum), which requires an open habitat. He attributed this decline to lack of grazing but also, perhaps, to aerial deposition of nitrogen, these being major factors leading to the rapid loss of early successional slack habitat. Varying rates of succession in duneslacks have been reported elsewhere in Britain and Europe. Thus, Grootjans et al. (1998) described secondary colonists enhancing productivity after 6-10 years, this process perhaps being accelerated by atmospheric nitrogen-deposition. In contrast, Van der Maarel et al. (1985) found that shifts from pioneer to more mature successional stages in Dutch dunes took as long as 20-30 years, while Adema et al. (2002) described calcareous dune-slacks in Texel, where early pioneer vegetation occurred side-by-side with more productive later stages, little change having taken place for over 62 years. They studied the soil chemistry of the infiltration and exfiltration sides of a slack, concluding that the infiltration side could not maintain pioneer vegetation for long because of the build-up of free sulphide which favours Phragmites australis over most pioneer species. This may be one of the reasons for rapid development of tall fen vegetation in the New Green Beach slack. At Tentsmuir, Crawford \& Wishart (1966) found that development of a mature Salix repens-Juncus balticus (Baltic Rush) slack from a young wetland with halophytic components took a minimum of 25 years. Similarly, by the end of their 17-year study of primary succession on a beachplain, Olff et al. (1993) showed that slacks supported increasing amounts of Bolboschoenus maritimus and Phragmites australis, while Agrostis stolonifera was still common.

\section{Vegetation classification}

Although Rodwell's (2000) keys gave an indication of NVC vegetation types in the study area, the quadrat data for New Green Beach slack habitats did not provide satisfactory matches to a wide range of community types. Poor statistical 
fits to NVC dune-slack communities have been reported previously on the Sefton Coast. These were attributed to the mosaic and often transitional nature of slack vegetation, the difficulty of selecting 'typical' stands and because small sample sizes were used to derive the original NVC communities (Smith, 2019; Rees, 2020; Stratford et al., 2014).

\section{Conservation}

The high species-richness of the New Green Beach, together with the presence of 41 notable species (16 Red-listed) (Table 2), confers a high nature conservation value (Davy et al., 2006). Most of the plants found are native species, the low frequency of non-natives probably being due to the distance of the site from the nearest gardens (about $1 \mathrm{~km}$ ) and the harsh maritime conditions. Twenty-nine (70\%) of the notable taxa are associated with the slack. Studies in The Netherlands have also established the importance of early-stage dune slacks for Red-listed plants, many of which are basiphilous and have declined severely in European dune systems over recent decades (Lammerts et al., 2001; Sival \& Grootjans, 1996; Sýkora et al., 2004). Calcicoles on the New Green beach, with Ellenberg R-values of 8, include Blackstonia perfoliata, Centaurium littorale, C. pulchellum and Samolus valerandi (Brookweed). Habitat conditions necessary for these rare basiphilous communities are a soil pH of 6-8, small pools of soil organic matter, nitrogen and phosphorus and appropriate ground-water chemistry (Lammerts et al., 2001). Quadrat pH measurements of 6.9 to 7.5 (mean and median 7.2) at the New Green Beach agree with the reported range for these soil types and their associated vegetation.

Like many other British and Northwest European coastal dune systems (Houston, 2008), the Sefton dunes, have become more heavily vegetated in recent decades leading to over-stabilisation and a low rate of slack formation. Early stage dune-slacks with pioneer basiphilous plant communities, such as those on the New Green Beach, are therefore rare on the Sefton Coast (Edmondson, 2010). These habitats were evidently much more common in the past but the collapse of rabbit populations due to disease, abandonment of livestock grazing, the introduction of non-native trees and shrubs, active management to stabilise the dunes, climate change and, probably, the aerial deposition of nitrogen have fundamentally altered the landscape and ecology of the dune system since the 1950s (Smith, 2009).

In addition to its botanical interest, the study site has other conservation values, its slack being a nationally important breeding site for the endangered natterjack toad (Epidalea calamita), though numbers of spawn strings peaked in 2008 and declined subsequently as the vegetation matured (Smith \& Skelcher, 2020). The frontal dune ridge is also important as terrestrial habitat for the natterjack and for invertebrates, such as the endemic sandhill rustic moth (Luperina nickerlii subsp. gueneel) (Flenley, 2012) and nationally rare northern dune tiger beetle (Cicindela hybrida) (Smith, 2011). Another section 41 species, the thallose liverwort, petalwort (Petalophyllum ralfsii), was recorded in 2017 and 
2020 at the southern end of the New Green Beach (Callaghan, 2021). With younger successional features having recently developed to the south of the study area (Fig. 1), this complex of habitats has outstanding nature conservation value and scientific interest. However, the rate of succession described here suggests that the high species richness particularly associated with the younger habitats could be transitory, being replaced within a few years by heavily vegetated fixed-dunes, tall-herb fen and carr woodland with different, potentially lower, conservation interests (Rees, 2020).

\section{Acknowledgements}

We are grateful to Catherine Highfield and Mike Wilcox for occasional assistance in the field. Mary Dean and James Page kindly provided copies of several scientific papers, as did Maike Isermann who helpfully translated Heykeyna's paper. James Page provided a translation of papers by Hansen and Riediger, while Natalie Hunt produced the site map, analysed the quadrats and provided details of the petalwort record in 2017.

\section{References}

Adema, E.B., Grootjans, A.P., Petersen, J. \& Grijpstra, J. 2002. Alternative stable states in a wet calcareous dune slack in The Netherlands. Journal of Vegetation Science 13: 107-114.

Allen, M.J. 1932. Recent changes in the sea-beach flora at Ainsdale, Lancashire. Northwestern Naturalist 24: 114-117.

Blanchard, B. 1952. An ecological survey of the vegetation of the sand-dune system of the south west Lancashire coast, with special reference to an associated marsh flora. Ph.D. thesis. University of Liverpool.

Bossuyt, B., Honnay, O. \& Hermy, M. 2003. An island biogeographical view of the successional pathway in wet dune slacks. Journal of Vegetation Science 14: 681-788.

Callaghan, D. 2021. Survey of Bryum calophyllum, B. warneum and Petalophyllum ralfsii on the Sefton Coast, Merseyside. Ainsdale: Natural England.

Clarke, D. \& Sanitwong Na Ayutthaya, S. 2010. Predicted effects of climate change, vegetation and tree cover on dune slack habitats at Ainsdale on the Sefton Coast, UK. Journal of Coastal Conservation 14: 115-125.

Connolly, P.A. 2006. Report on the evolution of the morphology of Smith's Slack, Birkdale, Merseyside. Sefton Council: Coast defence, Ainsdale-on-Sea.

Crawford, R.M.M. \& Wishart, D. 1966. A multivariate analysis of the development of dune slack vegetation in relation to coastal accretion at Tentsmuir, Fife. Journal of Ecology 54: 729-743.

Davy, A.J., Grootjans, A.P., Hiscock, K. \& Petersen, J. 2006. Development of ecohydrological guidelines for dune habitats - Phase 1. Research report no. 696. Peterborough: English Nature. 
Edmondson, S.E. 2010. Dune slacks on the Sefton Coast. In: Worsley, A.T., Lymbery, G., Holden, V.J.C. \& Newton, M., eds. Sefton's dynamic coast, pp. 178-187. Southport: Sefton Technical Services Department.

Edmondson, S.E., Traynor, H. \& McKinnell, S. 2001. The development of a green beach on the Sefton Coast, Merseyside, UK. In: Houston, J., Edmondson, S.E. \& Rooney, P.J., eds. Coastal dune management. Shared experience of European conservation practice, pp. 48-58. Liverpool: Liverpool University Press.

Flenley, D. 2012. The moth man's prophecies: an assessment of the predictive accuracy of a species distribution model for the Sandhill Rustic moth on the Sefton Coast. London: People's Trust for Endangered Species.

Grootjans, A.P., Ernst, W.H.O. \& Stuyfzand, P.J. 1998. European dune slacks: strong interactions of biology, pedogenesis and hydrology. Trends in Ecology and Evolution 13: 96-100.

Hansen, K. 2009. Pflanzensoziologische und pedologische Untersuchungen an sogeannten "Green Beaches" auf den Ostfriesichen Inseln; am Beispiel der Insel Spiekeroog. Diploma thesis. University of Oldenburg.

Heykeyna, A. 1965. Vegetationstypen der Küstendünen an der östlichen und südlichen Nordsee. Mitteilungen der Arbeitsgemeinschaft für Floristik in Schleswig-Holstein und Hamburg, 13:1-135.

Hill, M.O. 2015. Tablefit version 2.0 for identification of vegetation types. Wallingford: Centre for Ecology \& Hydrology.

Hill, M.O., Preston, C.D. \& Roy, D.B. 2004. PLANTATT. Attributes of British and Irish plants: status, size, life history, geography and habitats. Huntingdon: Centre for Ecology \& Hydrology.

Houston, J.A. 2008. Management of Natura 2000 habitats. 2190 humid dune slacks. Brussels: European Commission.

Isermann, M. 2011. Patterns in species diversity during succession of coastal dunes. Journal of Coastal Research 27: 661-671.

Isermann, M., Diekmann, M. \& Heeman, S. 2007. Effects of the expansion by Hippophae rhamnoides on plant species richness in coastal dunes. Applied Vegetation Science 10: 33-42.

James, P.A. 1993. Soils and nutrient cycling. In: Atkinson, D. \& Houston, J., eds. The sand dunes of the Sefton Coast, pp. 47-54. Liverpool: National Museums and Galleries on Merseyside.

Jones, M.L.M., Sowerby, A. \& Rhind, P.M. 2010. Factors affecting vegetation establishment and development in a sand dune chronosequence at Newborough Warren, North Wales. Journal of Coastal Conservation 14: 127-137.

Koppenaal, E.C. 2007. Green beaches; vegetation and abiotic conditions. Community \& Conservation Biology. University of Groningen.

Kristiansen, I.L. 2008. The development and conservation value of Alder (Alnus glutinosa) woodland on Birkdale green beach. M.Sc. dissertation. University of Edinburgh. 
Lammerts, E.J., Maas, C. \& Grootjans, A.P. 2001. Groundwater variables and vegetation in dune slacks. Ecological Engineering 17: 33-47.

McAleavy, D. 2010. Sefton beach management - twenty years of progress. In: Worsley, A.T., Lymbery, G., Holden, V.J.C. \& Newton, M., eds. Sefton's dynamic coast, pp. 318-326. Southport: Sefton Technical Services Department.

McVean, D.N. 1956. Ecology of Alnus glutinosa (L.) Gaertn: III. Seedling establishment. Journal of Ecology 44: 195-218.

Maun, M.A. 2009. The biology of coastal sand dunes. Oxford: Oxford University Press.

Odum, E.P. 1971. Fundamentals of ecology. $2^{\text {nd }}$. ed. Saint Louis: Saunders.

Olff, H., Huisman, J. \& Van Tooren, B.F. 1993. Species dynamics and nutrient accumulation during early primary succession in coastal sand dunes. Journal of Ecology 81: 693-709.

Packham, J.R. \& Willis, A.J. 1997. Ecology of dunes, salt marsh and shingle. London: Chapman \& Hall.

Page, J. 2018. The pedology of successional change in dune-slacks at Birkdale Green Beach, North Merseyside. B.Sc. thesis. University of Lancaster.

Ranwell, D.S. 1972. Ecology of salt marshes and sand dunes. London: Chapman \& Hall.

Rees, S. 2020. Definition of favourable conservation status for coastal sand dunes. Peterborough: Natural England.

Regional Biodiversity Steering Group 1999. A biodiversity audit of north west England. 2 vols. Bootle: Merseyside Environmental Advisory Service.

Riediger, J. 2009. Pflanzensoziologische und pedologische Untersuchungen von so genannten "Green Beaches" auf den Ostfriesichen Inseln - am Beispiel von Borkum und Langeoog. Diploma thesis. University of Oldenburg.

Robinson, N.A. 1971. Ainsdale Sand Dunes National Nature Reserve vegetation survey: August 1971. Ainsdale: Ainsdale Sand Dunes NNR archive.

Rodwell, J.S. ed. 1991. British plant communities Volume 1. Woodlands and scrub. Cambridge: Cambridge University Press.

Rodwell, J.S. ed. 1995. British plant communities Volume 4. Aquatic communities, swamps and tall-herb fens. Cambridge: Cambridge University Press.

Rodwell, J.S. ed. 2000. British plant communities Volume 5. Maritime communities and vegetation of open habitats. Cambridge: Cambridge University Press.

Salisbury, E.J. 1925. Note on the edaphic succession in some dune soils with special reference to the time factor. Journal of Ecology 13: 322-328.

Sival, F.P. \& Grootjans, A.P. 1996. Dynamics of seasonal bicarbonate supply in a dune slack: effects on organic matter, nitrogen pool and vegetation succession. Vegetatio, 126: 39-50.

Smith, P.H. 2006. Changes in the floristic composition of sand-dune slacks over a twenty-year period. Watsonia 26: 41-49. 
Smith, P.H. 2007. The Birkdale Green Beach - a sand-dune biodiversity hotspot. British Wildlife 19: 11-16.

Smith, P.H. 2009. The sands of time revisited: an introduction to the sand-dunes of the Sefton Coast. Stroud, Gloucestershire: Amberley Publications.

Smith, P.H. 2010. Birkdale Green Beach. In: Worsley, A.T., Lymbery, G., Holden, V.J.C. \& Newton, M., eds. Sefton's dynamic coast, pp. 194-200. Southport: Sefton Technical Services Department.

Smith, P.H. 2011. Seasonal abundance of Cicindela hybrida L. (Coleoptera: Carabidae) on the Sefton Coast sand-dunes, Merseyside. British Journal of Entomology and Natural History 24: 11-15.

Smith, P.H. 2017. The natural history of a sand-dune blowout. British Wildlife 28: 329-334.

Smith, P.H. 2019. Changing status of Blysmus compressus (Flat Sedge) in the Sefton Coast sand-dunes, north Merseyside, UK. British \& Irish Botany 1: 70-90.

Smith, P.H. 2020. Increasing status of non-native vascular plants in the Sefton Coast sand-dune system, north Merseyside, UK. British \& Irish Botany 2: 102-126.

Smith, P.H. \& Deed, B. 2014. A volunteer survey of Parnassia palustris (Grass-ofParnassus) on the Sefton Coast, Merseyside, v.c.59. BSBI News 127: 5-18.

Smith, P.H. \& Skelcher, G. 2019. Effects of environmental factors and conservation measures on a sand-dune population of the natterjack toad (Epidalea calamita) in north-west England: a 31-year study. Herpetological Journa/29: 146-154.

Stace, C.A. 2019. New flora of the British Isles. $4^{\text {th }}$ ed. Middlewood Green, Suffolk: C \& M Floristics.

Stratford, C., Jones, L., Robins, N., Mountford, O., Amy, S., Peyton, J., Hulmes, L., Hulmes S., Jones, F., Redhead, J., Dean, H., \& Palisse, M. 2014. Survey and analysis of vegetation and hydrological change in English dune slack habitats. Peterborough: Natural England commissioned report NECR153.

Stroh, P.A., Leach, S.J., August, T.A., Walker, K.J., Pearman, D.A., Rumsey, F.J., Harrower, C.A., Fay, M.F., Martin, J.P., Pankhurst, T., Preston, C.D. \& Taylor, I. 2014. A vascular plant red list for England. Bristol: Botanical Society of Britain and Ireland.

Sýkora, K.V., van den Bogert, J.C.J.M. \& Berendse, F. 2004. Changes in soil and vegetation during dune slack succession. Journal of Vegetation Science 15: 209-218.

Travis, W.H. 1916. The development of vegetation on the Lancashire dunes. Lancashire \& Cheshire Naturalist 9: 39-42; 66-69; 83-87.

Van der Maarel, E. 1977. Environmental management of coastal dunes in The Netherlands. In: Jeffries, R.L. \& Davy, A.J., eds. Ecological processes in coastal environments. 1st European ecological symposium and 19th symposium of the British Ecological Society, pp. 543-570. London: Blackwell. 
Van der Maarel, E., Boot, R.G.A., Van Dorp, D. \& Rijntjes, J. 1985. Vegetation succession on the dunes near Oostvoorne, The Netherlands: a comparison of the vegetation in 1959 and 1980. Vegetatio 58:137-187

Wheldon, J.A. \& Travis, W.H. 1923. The Lancashire sand dunes. In: Holt, A., ed. $A$ handbook to Liverpool and district prepared on the occasion of the meeting of the British Association for the Advancement of Science in Liverpool, September 1923, pp. 271-81. Liverpool: University Press of Liverpool.

Copyright retained by author(s). Published by BSBI under the terms of the Creative Commons Attribution 4.0 International Public License.

ISSN: $2632-4970$

https://doi.org/10.33928/bib.2021.03.232

Appendix 1. Regionally and nationally notable vascular plants recorded on the New Green Beach, 2005-2019 (Regional Biodiversity Steering Group, 1999; Stroh et al., 2014)

NR = Nationally Rare; NS = Nationally Scarce; VU = Vulnerable; NT = Near Threatened; LC = Least Concern (italics = England Red List, 2014); S41 = Threatened species listed under Section 41of the Natural Environment and Rural Communities

Act 2006; SCI = Species of Conservation Importance in North West England

\begin{tabular}{|l|l|l|l|l|l|}
\hline Taxon & English name & Status & Taxon & $\begin{array}{l}\text { English } \\
\text { name }\end{array}$ & Status \\
\hline $\begin{array}{l}\text { Anacamptis } \\
\text { pyramidalis }\end{array}$ & Pyramidal Orchid & SCI & $\begin{array}{l}\text { Myosotis } \\
\text { ramosissima }\end{array}$ & $\begin{array}{l}\text { Early Forget- } \\
\text { me-not }\end{array}$ & SCI \\
\hline Atriplex laciniata & Frosted Orache & SCI & $\begin{array}{l}\text { Oenanthe } \\
\text { lachenalii }\end{array}$ & $\begin{array}{l}\text { Parsley } \\
\text { Water- } \\
\text { dropwort }\end{array}$ & NTSCI \\
\hline Carex viridula & $\begin{array}{l}\text { Small-fruited } \\
\text { Yellow-sedge }\end{array}$ & SCI & Oxybasis rubra & $\begin{array}{l}\text { Red } \\
\text { Goosefoot }\end{array}$ & SCI \\
\hline Carlina vulgaris & Carline Thistle & SCI & Parnassia palustris & $\begin{array}{l}\text { Grass-of- } \\
\text { Parnassus }\end{array}$ & VUSCI \\
\hline Centaurium littorale & Seaside Centaury & NS SCI & Phleum arenarium & $\begin{array}{l}\text { Sand Cat's- } \\
\text { tail }\end{array}$ & SCI \\
\hline $\begin{array}{l}\text { Centaurium } \\
\text { pulchellum }\end{array}$ & Lesser Centaury & SCI & $\begin{array}{l}\text { Polygonum } \\
\text { oxyspermum } \\
\text { subsp. raii }\end{array}$ & $\begin{array}{l}\text { Ray's } \\
\text { Knotgrass }\end{array}$ & SCI \\
\hline $\begin{array}{l}\text { Comarum palustre } \\
\text { Comrola rotundifolia } \\
\text { subsp. maritima }\end{array}$ & $\begin{array}{l}\text { Round- } \\
\text { leaved } \\
\text { Wintergreen }\end{array}$ & $\begin{array}{l}\text { NS, } \\
\text { SCI }\end{array}$ \\
\hline $\begin{array}{l}\text { Dactylorhiza } \\
\text { incarnata subsp. } \\
\text { coccinea }\end{array}$ & $\begin{array}{l}\text { Early Marsh- } \\
\text { orchid }\end{array}$ & $\begin{array}{l}\text { NS NT } \\
\text { SCI }\end{array}$ & $\begin{array}{l}\text { Ranunculus } \\
\text { flammula }\end{array}$ & $\begin{array}{l}\text { Lesser } \\
\text { Spearwort }\end{array}$ & VU \\
\hline
\end{tabular}




\begin{tabular}{|l|l|l|l|l|l|}
\hline $\begin{array}{l}\text { Dactylorhiza } \\
\text { incarnata subsp. } \\
\text { incarnata }\end{array}$ & $\begin{array}{l}\text { Early Marsh- } \\
\text { orchid }\end{array}$ & SCI & Sagina nodosa & $\begin{array}{l}\text { Knotted } \\
\text { Pearlwort }\end{array}$ & VU \\
\hline $\begin{array}{l}\text { Dactylorhiza } \\
\text { purpurella }\end{array}$ & $\begin{array}{l}\text { Northern Marsh- } \\
\text { orchid }\end{array}$ & SCI & Salicornia fragilis & $\begin{array}{l}\text { Yellow } \\
\text { Glasswort }\end{array}$ & NS \\
\hline $\begin{array}{l}\text { Eleocharis } \\
\text { quinqueflora }\end{array}$ & $\begin{array}{l}\text { Few-flowered } \\
\text { Spike-rush }\end{array}$ & SCI & Salix xfriesiana & $\begin{array}{l}\text { Hybrid } \\
\text { Willow }\end{array}$ & NR \\
\hline Eleocharis uniglumis & $\begin{array}{l}\text { Slender Spike- } \\
\text { rush }\end{array}$ & SCI & Salix repens & $\begin{array}{l}\text { Creeping } \\
\text { Willow }\end{array}$ & NT \\
\hline Epipactis palustris & $\begin{array}{l}\text { Marsh } \\
\text { Helleborine }\end{array}$ & NTSCI & Salsola kali & $\begin{array}{l}\text { Prickly } \\
\text { Saltwort }\end{array}$ & $\begin{array}{l}\text { VU LC } \\
\text { S41 } \\
\text { SCI }\end{array}$ \\
\hline Eryngium maritimum & Sea Holly & NTSCI & Samolus valerandi & Brookweed & SCI \\
\hline Euphorbia paralias & Sea Spurge & SCI & $\begin{array}{l}\text { Schoenoplectus } \\
\text { tabernaemontani }\end{array}$ & $\begin{array}{l}\text { Grey Club- } \\
\text { rush }\end{array}$ & SCI \\
\hline Euphrasia confusa & $\begin{array}{l}\text { Confused } \\
\text { Eyebright }\end{array}$ & VU & Thalictrum flavum & $\begin{array}{l}\text { Common } \\
\text { Meadow-rue }\end{array}$ & SCI \\
\hline Euphrasia nemorosa & $\begin{array}{l}\text { Common } \\
\text { Eyebright }\end{array}$ & NT & $\begin{array}{l}\text { Trifolium } \\
\text { fragiferum }\end{array}$ & $\begin{array}{l}\text { Strawberry } \\
\text { Clover }\end{array}$ & SCI \\
\hline $\begin{array}{l}\text { Euphrasia } \\
\text { tetraquetra }\end{array}$ & NTSCI & $\begin{array}{l}\text { Triglochin } \\
\text { palustris }\end{array}$ & $\begin{array}{l}\text { Marsh } \\
\text { Arrowgrass }\end{array}$ & NT SCI \\
\hline Hydrocotyle vulgaris & Marsh Pennywort & NT & $\begin{array}{l}\text { Valeriana } \\
\text { officinalis }\end{array}$ & $\begin{array}{l}\text { Common } \\
\text { Valerian }\end{array}$ & NT \\
\hline Juncus maritimus & Sea Rush & SCI & Vulpia fasciculata & Dune Fescue & NS \\
\hline Juncus ranarius & Frog Rush & SCI & & & \\
\hline
\end{tabular}

